\title{
Simultaneous Biological Pretreatment and Saccharification of Rice Straw by Ligninolytic Enzymes from Panus neostrigosus I9 and Commercial Cellulase
}

\author{
Ariyah Terasawat (D) and Sivawan Phoolphundh *(D) \\ Department of Microbiology, Faculty of Science, King Mongkut's University of Technology Thonburi, \\ 126 Pracha-Uthid Road, Bang Mod, Thungkru, Bangkok 10140, Thailand; Ariyah.tera@mail.kmutt.ac.th \\ * Correspondence: sivawan.pho@kmutt.ac.th; Tel.: +66-24708887
}

Citation: Terasawat, A.;

Phoolphundh, S. Simultaneous

Biological Pretreatment and

Saccharification of Rice Straw by Ligninolytic Enzymes from Panus neostrigosus 19 and Commercial Cellulase. J. Fungi 2021, 7, 853. https://doi.org/10.3390/jof7100853

Academic Editor: Laurent Dufossé

Received: 9 September 2021

Accepted: 5 October 2021

Published: 12 October 2021

Publisher's Note: MDPI stays neutral with regard to jurisdictional claims in published maps and institutional affiliations.

Copyright: (c) 2021 by the authors. Licensee MDPI, Basel, Switzerland. This article is an open access article distributed under the terms and conditions of the Creative Commons Attribution (CC BY) license (https:// creativecommons.org/licenses/by/ $4.0 /)$.
Abstract: The utilization of rice straw for biofuel production is limited by its composition. The pretreatment process is required to improve the enzymatic accessibility of polysaccharides in the biomass prior to enzymatic saccharification. In this study, simultaneous biological pretreatment and saccharification (SPS) of rice straw starting from laccase production by Panus neostrigosus I9 was operated in a 2-L fermenter. It was found that fungal physiology was strongly influenced by the agitation, and that the highest laccase production was obtained at an agitation speed of $750 \mathrm{rpm}$ $(209.96 \pm 0.34 \mathrm{U} / \mathrm{L})$. The dilution rate of $0.05 \mathrm{~h}^{-1}$ was set in continuous fermentation which resulted in laccase activity of $678.49 \pm 20.39 \mathrm{U} / \mathrm{L}$, approximately three times higher than that in batch culture. Response surface methodology (RSM) was applied to achieve the condition for maximum percentage of delignification. The maximum percentage of delignification of $45.55 \%$ was accomplished after pretreatment of rice straw with laccase enzyme $39.40 \mathrm{U} / \mathrm{g}$ rice straw at $43.70{ }^{\circ} \mathrm{C}$ for $11.19 \mathrm{~h}$. Reducing sugar of $3.85 \pm 0.15 \mathrm{~g} / \mathrm{L}$ was obtained from the digested rice straw in a SPS reactor, while nonpretreated rice straw gave only $1.13 \pm 0.10 \mathrm{~g} / \mathrm{L}$ within $12 \mathrm{~h}$ of incubation. The results indicated that simultaneous biological pretreatment and saccharification (SPS) of rice straw by laccase helped to improve the accessibility of cellulose by cellulolytic enzymes.

Keywords: laccase; white-rot fungi; continuous fermentation; biological pretreatment

\section{Introduction}

Thailand has a variety of lignocellulosic biomasses, with rice straw being the most abundant agricultural waste. The utilization of rice straw for biofuel production is limited by its composition [1], as it consists of cross-linked polymers of cellulose, hemicellulose, and lignin. These structures provide impermeability and resistance to oxidative stress and microbial attack [2]. Therefore, structural modification and removal of lignin during the pretreatment process are required to improve the enzymatic accessibility of polysaccharides in the biomass prior to enzymatic saccharification and subsequent fermentation.

Acid and alkaline pretreatments effectively solubilize lignin and hydrolyze hemicellulose, but acid causes corrosion to the internal structures of the bioreactor [3] while alkali removes uronic acid substitutions on hemicellulose, reducing the accessibility of hemicellulose to hydrolytic enzymes [4]. The use of steam explosion for biomass pretreatment requires a high energy input and leads to the destruction of the xylan fraction, the formation of toxic and inhibitory phenolic compounds, and incomplete digestion of the lignin-carbohydrate matrix [5]. Biological pretreatment is a new type of pretreatment that uses enzymes to digest the complex structure of lignocellulose. Since highly specific enzymes are used in this process, it results in a high level of digestible solids, low sugar degradation, low toxicity, low energy consumption, fermentation compatibility, simplicity, and environmental friendliness. The ligninolytic enzymes were used for biological pretreatment. However, it is not easy to find the enzyme suitable for this process because 
slow degradation rates and possible consumption of the substrate by the organisms have been observed $[3,6,7]$. The optimized operating parameters can reduce the pretreatment time and increase the yield of monomeric sugar at minimal cost. Among these organisms, filamentous fungi and especially white rot basidiomycetes are the most efficient lignin degraders [8].

White rot fungi have been studied for their biodegradability for several decades [6,9]. They are called selective degraders because they attack the lignin component of wood, while cellulose and hemicellulose are less affected. It is reported that white rot fungi mostly colonize dead or living wood and can degrade lignin efficiently under natural conditions [10]. Lignin was removed by ligninolytic enzymes, such as laccase, manganese peroxidase $(\mathrm{MnP})$, and lignin peroxidase $(\mathrm{LiP})$, leaving the valuable cellulose intact. Furthermore, many reports on these fungi show a diversity of lignin degradation efficiency, enzyme patterns and substrates that promote lignin degradation [11,12].

Laccases (benzenediol oxygen oxidoreductase) are multicopper phenol oxidases that oxidize phenolic compounds to phenoxyl radicals and oxidize some nonphenolic compounds in the presence of a mediator, such as 2,2-azinobis (3-ethylbenzthiazoline-6sulfonate) (ABTS) or 1-hydroxybenzotriazole [8]. The first laccase was isolated from plants, but also found in some fungi and bacteria [13]. The largest amounts of laccase are produced by white rot fungi [14]. In general, laccases are ligninolytic enzymes secreted into the surrounding medium by these fungi for various processes, such as lignin degradation, sporulation, pigment production, fruiting body formation, and plant pathogenesis [15]. It is believed that the ligninolytic enzymes of whit rot fungi are produced during secondary metabolism and normally under nitrogen deficiency [10]. The ligninolytic enzymes are usually obtained from cultured white rot fungi by solid-state fermentation, but the problem is the slow cultivation of white rot fungi on wood and their sensitivity to growth conditions [16-18].

Liquid or submerged fermentation has also been used favorably for enzyme production. Submerged fermentation (SMF) is the growth of microorganisms in a liquid medium associated with a high concentration of nutrients and oxygen (aerobic conditions). The morphology that develops in filamentous fungi in submerged culture influences both production and bioreactor control [19]. The two morphological differences during cultivation affect the mass transfer within the fermenter tank. First, the shape of the free mycelia increases the apparent viscosity, which can alter the rheological behavior of the non-Newtonian fluid (shear thinning or pseudoplasticity) [20]. This reduces mixing and air distribution, leading to limitations in solid-fluid mass transfer and oxygen transfer in the liquid medium. Second, the pellet shape restricts mass transfer within the particles. These limitations can lead to regions with different growth patterns and substrates. The outer zone is metabolically active, while zones of low viability exist inside the pellet. Therefore, both the rheology of the fermentation broth and the performance of the bioreactor have a significant impact on the morphological growth forms of the fungi [21]. Usually, stirred tanks (STR) provide efficient mixing of the fermentation broth and ensure adequate oxygen transport in the tanks. Although high agitation ensures good mixing, it can also generate high shear forces that can affect filamentous microorganisms, such as biomass concentration, morphological changes, cell wall breakage, variations in the rate of synthesis of products, and overall growth rate $[19,22,23]$.

Results from our previous work showed that Panus neostrigosus I9, a fast-growing white rot fungus, could produce high laccase enzyme activity when cultured in V8 medium which has tomato juice as main composition [24]. However, large production of ligninolytic enzymes at low cost is required for its application [25]. Therefore, tomato juice can be another good choice to use as a medium for economic laccase production. In addition, laccase production by $P$. neostrigosus I9 was investigated as a function of physicochemical parameters under submerged cultivation [26]. This can be achieved by operating the reactor in a continuous mode. When laccase is secreted by the fungi, the cells grown in perfusion act as a renewable catalyst for continuous production as fresh medium washes 
out the secreted products into the environment. Therefore, the feasibility and advantages of continuous operation of STR were also investigated for laccase production.

Normally, the pretreatment process must be separated with the hydrolysis process, which consumes more time, energy, and cost. The ligninolytic enzyme of P. neostrigosus I9 could be mixed with the cellulase enzyme to create the single-step simultaneous biological pretreatment and saccharification process (SPS). Therefore, continuous laccase production is required for the continuous process. The aims of this research are (1) to achieve high production of laccase enzyme from P. neostrigosus I9 in continuous fermentation; and (2) to optimize the pretreatment conditions for the production of reducing sugars from rice straw by ligninolytic enzymes and cellulolytic enzymes using response surface methodology (RSM) to achieve high digestible solids content, low sugar degradation, low toxicity, and low energy consumption in a single-step SPS. In particular, SPS by ligninolytic enzymes is another option for a less chemical and environmentally friendly process to use biomass as feedstock for biofuel production.

\section{Materials and Methods}

\subsection{Microorganism}

The white rot fungus 19 was obtained from the Department of Microbiology at KMUTT and identified as Panus neostrigosus at Mycology Laboratory, National Center for Genetic Engineering and Biotechnology, Thailand. The fungal colonies of P. neostrigosus 19 from stock cultures were transferred to potato dextrose agar (PDA) plates (Himedia Inc.) and incubated at $30^{\circ} \mathrm{C}$ for four days.

\subsection{Cultivation of Panus neostrigosus I9 in the Stirred Tank for Laccase Production \\ 2.2.1. Inoculum Preparation}

Tomato juice medium was prepared by diluted tomato juice (Doi Kham Food Product Co., Ltd., Chiang Rai, Thailand) with distilled water at a ratio of 1:3 v/v (initial total carbohydrate approximately $15 \mathrm{~g} / \mathrm{L}$ ) and adjusted to $\mathrm{pH}$ 5.0. The 250-mL flask containing $100 \mathrm{~mL}$ of tomato juice medium was sterilized at $121^{\circ} \mathrm{C}, 103 \mathrm{kPa}$ for $15 \mathrm{~min}$. Two plugs of $P$. neostrigosus $\mathrm{I} 9$ (diameter $1 \mathrm{~cm}$ ) cultured on PDA plates at $30^{\circ} \mathrm{C}$ for four days were transferred to each flask. The culture was incubated at $28^{\circ} \mathrm{C}$ with shaking at $150 \mathrm{rpm}$ for four days. One hundred milliliters of cultured P. neostrigosus 19 which had a biomass dry weight of approximately $0.5 \mathrm{~g} / 100 \mathrm{~mL}$ were used as inoculum size in the stirred tank reactor.

\subsubsection{Cultivation of Panus neostrigosus I9 in Batch Fermentation}

Batch culture was carried out in a 2-L stirred tank reactor containing $1.35 \mathrm{~L}$ of tomato juice medium (dilution 1:3 v/v) pH 5.0 (after sterilization). Prior to use, the empty bioreactor was autoclaved at $121{ }^{\circ} \mathrm{C}$ and a vapor pressure of $103 \mathrm{kPa}$ for $15 \mathrm{~min}$ to prevent the contamination that may occur from the material. The tank was sterilized again after adding the tomato juice medium. The prepared inoculum $(100 \mathrm{~mL})$ was transferred to the reactor and $50 \mathrm{~mL}$ of sterilized tomato juice medium was added to the tank to increase the working volume to $1.5 \mathrm{~L}$. The system was operated at $28^{\circ} \mathrm{C}$ with one vvm aeration and $750 \mathrm{rpm}$ agitation for $120 \mathrm{~h}$. Every $4 \mathrm{~h}$, two milliliters of sample was collected in triplicate and centrifuged at $10,000 \mathrm{rpm}$ for $10 \mathrm{~min}$ at $4{ }^{\circ} \mathrm{C}$. The supernatant was immediately assayed for laccase activity, while the precipitate was used for biomass analysis. The remain supernatant was stored at $-20^{\circ} \mathrm{C}$ for total carbohydrate analysis.

Data collected during batch fermentation were used to create a model of microbial growth and a model of laccase formation.

\subsubsection{The Model of Microbial Growth}

$\mathrm{t}=$ Time (hour)

$x=$ biomass concentration $(\mathrm{g} / \mathrm{L})$

$x_{m}=$ maximum biomass concentration $(\mathrm{g} / \mathrm{L})$ 
$x_{0}=$ Initial biomass concentration $(\mathrm{g} / \mathrm{L})$

$\mu_{m}=$ maximum specipic growth rate $\left(\mathrm{h}^{-1}\right)$

The microbial growth model follows the model of Elibol \& Mavituna [27] (Equation (1)). A plot of $\ln \frac{x_{t}}{\left(x_{m}-x_{t}\right)}$ versus time ( $\left.\mathrm{t}\right)$ will give a line of the slope and the vertical intercept equal to $\mu_{m}$ and $-\left(\ln \frac{x_{m}}{x_{0}}-1\right)$. Moreover, $\mu_{m}$ and $x_{0}$ can be determined using $x_{t}$ and $x_{m}$, respectively, and the fungal growth model can thus be constructed. The initial biomass concentration $\left(x_{0}\right)$ plays a crucial role in increasing the total biomass production. The rate of biomass production is determined by the characteristics of fungal growth. The specific growth rate $(\mu)$ depends only on the fungal characteristics.

$$
\ln \frac{x_{t}}{\left(x_{m}-x_{t}\right)}=\mu_{m} t-\left(\ln \frac{x_{m}}{x_{0}}-1\right)
$$

\subsubsection{Model of Laccase Formation}

$A=$ Coefficient for growth-associated production rate $(\mathrm{U} / \mathrm{g})$

$\beta=$ Coefficient for non-growth-associated production rate $(\mathrm{U} / \mathrm{g} \cdot \mathrm{hr}))$

$\mathrm{E}=$ laccase activity $(\mathrm{U} / \mathrm{L})$

$\mathrm{E}_{0}=$ Initial laccase activity $(\mathrm{g} / \mathrm{L})$

$\mathrm{S}=$ Total carbohydrate $(\mathrm{g} / \mathrm{L}), \mathrm{s}_{0}$ initial substrate concentration $(\mathrm{g} / \mathrm{L})$

The basis of the kinetics of product formation was calculated using the equation Luedeking-Piret (Equation (2)).

$$
\frac{d E}{d T}=\alpha \frac{d x}{d t}+\beta x
$$

And Zhao et al. [28] evaluated equation for laccase formation in Equation (3)

$$
\begin{gathered}
\mathrm{E}=\alpha \mathrm{A}(\mathrm{t})+\beta \mathrm{B}(\mathrm{t}) \\
\mathrm{A}(\mathrm{t})=x_{0}\left\{\frac{\mathrm{e}^{\mu_{m} \mathrm{t}}}{1-\left(x_{0} / x_{m}\right)\left(1-\mathrm{e}^{\mu_{m} \mathrm{t}}\right)}-1\right\} \\
\mathrm{B}(\mathrm{t})=\frac{x_{m}}{\mu_{m}} \ln \left\{1-\frac{x_{0}}{x_{m}}\left(1-\mathrm{e}^{\mu_{m} \mathrm{t}}\right)\right\} \\
\frac{d E}{d T}=\beta x_{m}
\end{gathered}
$$

A slope value from a plot of $\mathrm{E}-\beta \mathrm{B}(\mathrm{t})$ against time $\mathrm{A}(\mathrm{t})$ gives $\alpha$. A is a growthassociated constant $(\mathrm{U} / \mathrm{g})$ and $\beta$ is a biomass-associated constant $(\mathrm{U} /(\mathrm{g} \cdot \mathrm{hr}))$ when $d x / d t=0$ and $x=x_{m}$. $\beta$ can be obtained by means of Equation (4). Therefore, $\beta$ was calculated by dividing the productivity rate and the maximum biomass concentration in the stationary phase. $Y_{E G}$ represents the laccase yield of glucose $(\mathrm{U} / \mathrm{g})$ (Equation (5)), and $Y_{E G}$ is the biomass-specific yield of laccase (U/g) (Equation (6)).

$$
\begin{gathered}
Y_{E G}=\frac{E_{f}-E_{0}}{S_{0}-S_{f}} \\
Y_{E X}=\frac{E_{f}-E_{0}}{x_{0}-x_{f}}
\end{gathered}
$$

\subsubsection{Cultivation of Panus neostrigosus I9 in Continuous Fermentation}

Like batch culture, continuous fermentation was carried out in a 2-L stirred tank reactor containing $1.35 \mathrm{~L}$ of tomato juice medium (dilution 1:3 v/v) pH 5.0 (after sterilization) at $28^{\circ} \mathrm{C}$ with aeration of $1 \mathrm{vvm}$ and agitation at $750 \mathrm{rpm}$. Continuous fermentation started after $24 \mathrm{~h}$ batch cultivation and then operated continuously at a dilution rate of $0.05 \mathrm{~h}^{-1}$. The volume of the liquid fermenter was controlled with a peristaltic pump so that the feed rate of the medium exactly matched the efflux rate. Five milliliters of samples were collected in triplicate every $12 \mathrm{~h}$ and centrifuged at $10,000 \mathrm{rpm}$ for $10 \mathrm{~min}$ at $4{ }^{\circ} \mathrm{C}$. The supernatant 
was immediately analyzed for laccase activity, while the precipitate was used for biomass analysis. The residues were stored at $-20^{\circ} \mathrm{C}$ for determination of total carbohydrate.

Continuous laccase fermentation yielded a laccase activity of $678.49 \mathrm{U} / \mathrm{L}$, with a residence time of $20 \mathrm{~h}$. The fermentation broth was filtered with $0.45 \mu \mathrm{m}$ of glass fiber filter paper and diluted two-fold with McIlvaine buffer $\mathrm{pH} 5.0$ to serve as crude enzyme for biological pretreatment.

\subsection{Optimization of Lignocellulosic Biomass Pre-Treatment Process}

2.3.1. Rice Straw Preparation

Sun-dried rice straw was obtained from a Thai rice farm and was chopped with a laboratory chopper to the length $10-15 \mathrm{~cm}$. The gridded mixer was separeted using sieve at 40 mesh. The obtained rice straw powder (size approximately $0.4-0.5 \mathrm{~mm}$ ) was dried at $105{ }^{\circ} \mathrm{C}$ until there was no change in weight and stored in an airtight desiccator.

\subsubsection{Optimization of Lignocellulosic Biomass Pre-Treatment Process}

Two grams of dried, ground rice straw was pretreated with $100 \mathrm{~mL}$ of crude enzyme from P. neostrigosus I9 in a 250-mL Erlenmeyer flask. A Box-Behnken design with three levels $(-1,0,+1)$ and three factors (laccase concentration, $(10,25,40 \mathrm{U} / \mathrm{g}$ rice straw); time for pretreatment $(1,6.5,12 \mathrm{~h})$; and temperature, $\left(30,45,60^{\circ} \mathrm{C}\right)$ (Table 1$)$ were used to determine the optimum conditions of the pretreatment process for the delignification of lignocellulosic biomass using Design expert ${ }^{\circledR}$ version 6.0 (Minneapolis, MN, USA). The coefficients of the response surface equation were determined using Design Expert ${ }^{\circledR}$ Software.

Table 1. Factors level for design a Box-Behnken experiment of delignification of rice straw.

\begin{tabular}{cccc}
\hline \multirow{2}{*}{ Factor } & Low & Medium & High \\
\cline { 2 - 4 } & $\mathbf{- 1}$ & $\mathbf{0}$ & $\mathbf{1}$ \\
\hline Temperature & 30 & 45 & 60 \\
time & 1 & 6.5 & 12 \\
Laccase concentration & 10 & 25 & 40 \\
\hline
\end{tabular}

\subsubsection{Pretreatment Method}

Three pretreatment methods, i.e., steam explosion [29], acid treatment [30], and biopretreatment by crude enzyme from P. neostrigosus 19 , was used to pretreat ground rice straw compared with non-pretreated rice straw.

\section{Steam Explosion}

Ten grams of ground rice straw was subjected to autocatalytic steam explosion at $180^{\circ} \mathrm{C}$ and a vapor pressure of $900 \mathrm{kPa}$ for $4 \mathrm{~min}$, and the solid fraction of the pretreated slurry was collected by vacuum filtration. The collected solid fraction was then dried at $70{ }^{\circ} \mathrm{C}$ until constant weight. The dried material was then hydrolyzed with a commercial cellulolytic enzyme (Celluclast ${ }^{\circledR} 1.5 \mathrm{~L}$, produced by Trichoderma reesei).

\section{Acid Pretreatment}

Ten grams of ground rice straw was subjected to deacetylation with $0.1 \mathrm{~mol} / \mathrm{L} \mathrm{H}_{2} \mathrm{SO}_{4}$ at $121^{\circ} \mathrm{C} 103 \mathrm{Pka}$ for $1 \mathrm{~h}$ (solid:liquid ratio 1:6). Then, the pretreated slurry was adjusted to $\mathrm{pH} 5.0$ with $10 \mathrm{M}$ of $\mathrm{NaOH}$. The solid fraction of the pre-treated slurry was filtered and dried at $70{ }^{\circ} \mathrm{C}$ until constant weight. The dried material was then hydrolyzed with a commercial cellulolytic enzyme (Celluclast ${ }^{\circledR} 1.5 \mathrm{~L}$, produced by Trichoderma reesei).

Biological Pretreatment

Two grams of dried milled rice straw were pretreated with $100 \mathrm{~mL}$ of crude P. neostrigosus 19 enzyme under optimal conditions (incubation at $43{ }^{\circ} \mathrm{C}$ and $40 \mathrm{U} / \mathrm{g}$ rice straw for $11.37 \mathrm{~h}$ ) in a $250-\mathrm{mL}$ Erlenmeyer flask. The pretreated rice straw was dried at $70{ }^{\circ} \mathrm{C}$ until 
constant weight. The percentage of delignification and structure (FTIR analysis) before and after pretreatment were analyzed. The dried material was then hydrolyzed with a commercial cellulolytic enzyme (Celluclast ${ }^{\circledR} 1.5 \mathrm{~L}$, produced by Trichoderma reesei).

Enzymatic Hydrolysis

Enzymatic hydrolysis was carried out using commercial cellulolytic enzymes (Celluclast ${ }^{\circledR}$ $1.5 \mathrm{~L}$, produced by Trichoderma reesei). Two grams of unpretreated or pretreated rice straw was placed in a 250-mL Erlenmeyer flask containing $100 \mathrm{~mL}$ of phosphate buffer $\mathrm{pH}$ 6.0. The cellulolytic enzymes were added to the flask at a dose of $20 \mathrm{FPU} / \mathrm{g}$ rice straw after the pretreatment process. The reaction mixture was incubated in a rotary shaker at $150 \mathrm{rpm}$ and $50^{\circ} \mathrm{C}$ for $48 \mathrm{~h}$. One milliliter sample was taken every $6 \mathrm{~h}$ and centrifuged at 10,000 rpm for $5 \mathrm{~min}$. The supernatants were assayed for reducing sugars, as well as laccase and cellulase activity.

\subsection{Simultaneous Pretreatment and Saccharification of Rice Straw}

Milled rice straw was hydrolyzed simultaneously by mixing crude enzyme from $P$. neostrigosus I9 under optimization conditions and Celluclast ${ }^{\circledR}(20 \mathrm{FPU} / \mathrm{g}$ rice straw) in a 2.0-L reactor tank at a working volume of $1.5 \mathrm{~L}$ and a rotation speed of $150 \mathrm{rpm}$. Nonpretreated rice straw was hydrolyzed with only $20 \mathrm{FPU} / \mathrm{g}$ rice straw of Celluclast ${ }^{\circledR}$ in a 2.0-L reactor tank at a working volume $1.5 \mathrm{~L}$ and a rotation speed of $150 \mathrm{rpm}$. Samples $(1 \mathrm{~mL})$ were taken from each tank every $6 \mathrm{~h}$ and centrifuged at 10,000 rpm for $5 \mathrm{~min}$. The supernatant was concentrated by tangential crossflow $10 \mathrm{kDA}$ cut-off filtration (Pall corp.) and analyzed for reducing sugars and laccase activity.

\subsection{Analysis Methods}

\subsubsection{Biomass Composition of Rice Straw}

The content of cellulose, hemicellulose, and lignin was analyzed according to the analytical procedure [31] in Standard Biomass Analytical Methods provided by National Renewable Energy Laboratory (NREL).

\subsubsection{Percentage of Delignification}

The kappa number test was used to estimate the lignin content by measuring the oxidant demand of the pulp. Kappa numbers were performed on air-dried rice straw samples, which were dried on a heated balance to obtain their oven-dried weight. Rice straw was then treated with potassium permanganate $\left(\mathrm{KMnO}_{4}\right)$ according to TAPPI Classical Method T $236 \mathrm{~cm}-85$ "Kappa number of pulp" [32]. The kappa number was converted to Klason lignin using Equation (7). Finally, the percentage of delignification was calculated using Equation (8).

$$
\begin{gathered}
K l=K \times 0.13 . \\
\text { \%delignification }=\frac{K l_{i}-K l_{f}}{K l_{i}} \times 100
\end{gathered}
$$

$K=$ kappa number

$K l=$ Kalson lignin

$\%$ delignification $=$ Percentage of delignification

\subsubsection{Enzyme Assay}

Laccase activity was determined colorimetrically by modification of Rodriguez et al. [14]. The reaction mixture contained $1000 \mu \mathrm{L}$ of crude supernatant, $100 \mu \mathrm{L} 2 \mathrm{mM}$ of ABTS in a 25-mM sodium succinate buffer $\mathrm{pH} 5$ and $900 \mu \mathrm{L}$ of deionized water. The oxidation of 2,2" -azino-bis-3-ethylbenzthiozoline-6-sulfonic acid (ABTS) was monitored by determining the increase in absorbance at $436 \mathrm{~nm}$ after one minute incubation at $30{ }^{\circ} \mathrm{C}$. Extinction coefficient $(\varepsilon)$ of laccase at $436 \mathrm{~nm}=29,300 \mathrm{M}^{-1} \mathrm{~cm}^{-1}$. One unit of enzyme activity (U) is 
defined as the amount of enzyme that produces $1 \mu \mathrm{mol}$ of product per minute under the assay conditions.

Cellulase activity was determined using the filter paper activity (FPA) assay [33]. The crude enzyme (100 $\mu \mathrm{L}$ ) was incubated with $400 \mu \mathrm{L}$ of 50 -mM sodium citrate buffer (pH 5.0) containing filter paper Whatman No. $1(5 \mathrm{mg} / \mathrm{mL})$. The reaction mixture was incubated at $50{ }^{\circ} \mathrm{C}$ for $30 \mathrm{~min}$ and the reaction was stopped by adding $500 \mu \mathrm{L}$ of 3,5-dinitrosalicylic acid (DNS) reagent. The solution was placed in a water bath at $95^{\circ} \mathrm{C}$ for $5 \mathrm{~min}$, then $2 \mathrm{~mL}$ of distilled water was added, and the absorbance was measured using a spectrophotometer at $540 \mathrm{~nm}$. The absorbance was converted to concentration using the standard glucose curve. One unit of enzyme activity $(\mathrm{U})$ is defined as the amount of enzyme that produces $1 \mu \mathrm{mol}$ of reducing sugar per minute under the assay conditions.

\subsubsection{Total Carbohydrate Assay by Phenol-Sulfuric Method}

According to the phenol-sulfuric method [34], the total carbohydrate was determined using the $5 \%$ phenol solution and D-glucose as standard. One milliliter of the sample was mixed with $1 \mathrm{~mL}$ of $5 \%$ phenol solution and $5 \mathrm{~mL}$ of $98 \%$ sulfuric acid was added, boiled for $5 \mathrm{~min}$, and cooled at room temperature. The solution was measured at $480 \mathrm{~nm}$ using a spectrophotometer. The absorbance was converted to concentration using the standard glucose curve $(0-100 \mathrm{mg} / \mathrm{L})$.

\subsubsection{Reducing Sugar Assay by DNS Method}

Total reducing sugar was determined by the 3,5-dinitrosalicylic acid (DNS) assay [35] using D-glucose as standard. Next, $500 \mu \mathrm{L}$ of the sample was mixed with $500 \mu \mathrm{L}$ of DNS. The solution was placed in a water bath at $95^{\circ} \mathrm{C}$ for $5 \mathrm{~min}$. Then, $2 \mathrm{~mL}$ of distilled water was added, and the solution was measured using a spectrophotometer at $540 \mathrm{~nm}$. The absorbance was converted to concentration using the standard glucose curve. The yield of reducing sugar was calculated using the following Equation (9).

$$
\text { Reducing sugar yield }(\%)=\frac{\text { Reducing sugar }\left(\frac{g}{L}\right) \times 0.9 \times 100}{\text { thgiew of rice straw }\left(\frac{g}{L}\right)}
$$

\subsubsection{FTIR Spectrum Analysis}

Fourier Transform Infrared Spectroscopy of the untreated and pretreated rice straw was recorded using FTIR Thermo Nikolet 6700 (Waltham, MA, USA). Samples were used in the form of $\mathrm{KBr}$ discs prepared by grinding $1 \mathrm{mg}$ of sample/100 $\mathrm{mg}$ of pre-dried $\mathrm{KBr}$. The spectra were recorded in the range of $400-4000 \mathrm{~cm}^{-1}$ [7]. The obtained FTIR spectra were compared in terms of shift of peaks for different functional groups associated with different components of lignocellulosic biomass.

\subsection{Statistical Analysis}

All experiments were performed in triplicate and the values are the average of three values. The reducing sugar production during biological pretreatment and hydrolysis was analyzed using analysis of variance (ANOVA) (with a confidence level of 95\%).

\section{Results}

\subsection{Determination of Kinetic Models of P. neostrigosus I9}

Batch fermentation of $P$. neostrigosus I9 was carried out in 2.0-L STR with working a volume of $1.5 \mathrm{~L}$ at $750 \mathrm{rpm}, \mathrm{pH} 5.0$, and $28^{\circ} \mathrm{C}$. The dry weight of the fungus and laccase activity are shown in Figure 1. 

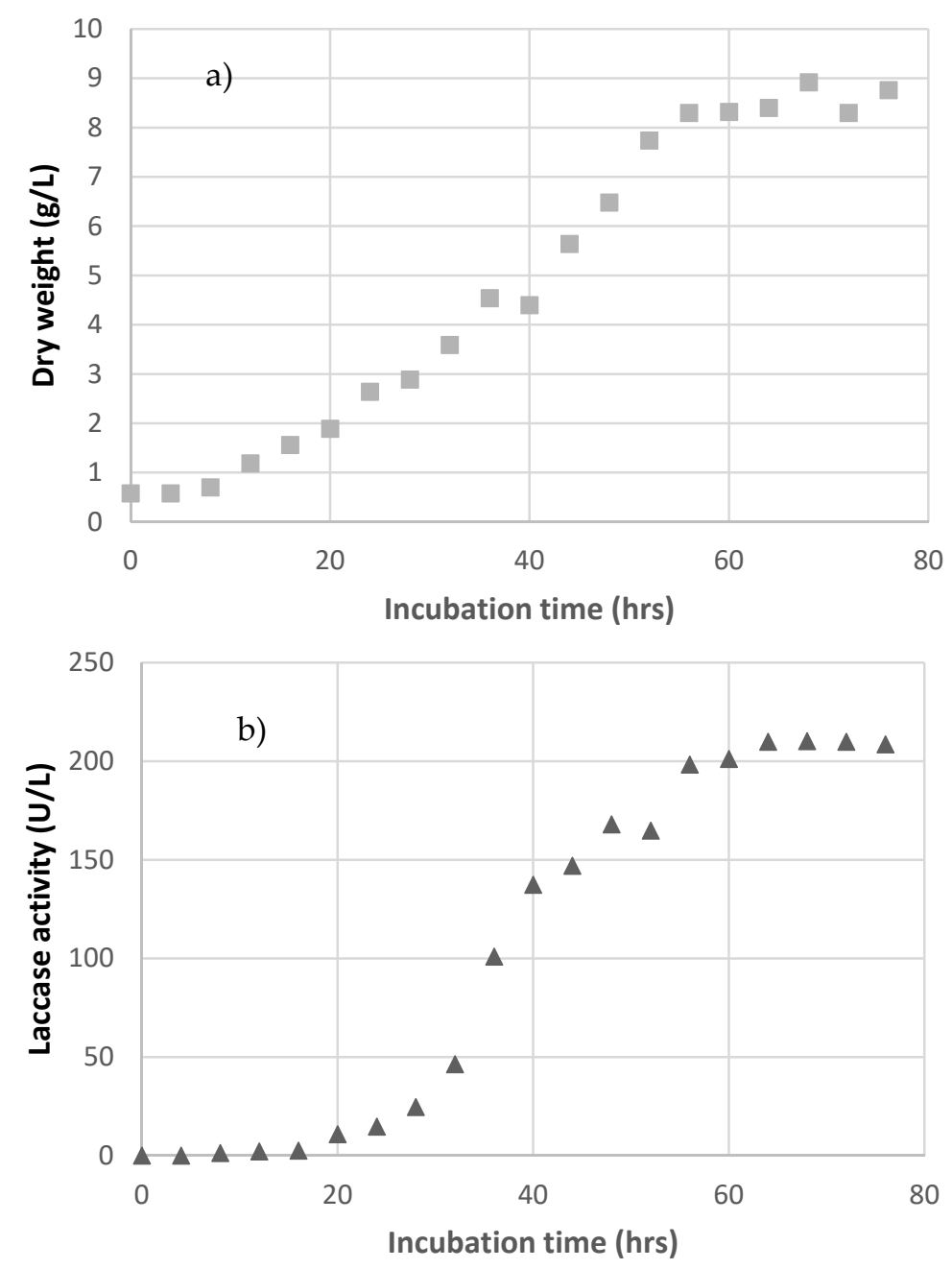

Figure 1. Time course study of dry weight (a) and laccase activity (b) during batch cultivation of $P$. neostrigosus $\mathrm{I} 9$ in $1.5 \mathrm{~L}$ tomato juice medium (diluted $1: 3 \mathrm{v} / \mathrm{v}$ ) at $28^{\circ} \mathrm{C}, 750 \mathrm{rpm}$.

\subsubsection{The Model of Fungal Growth Kinetics}

The increase in fungal dry weight was consistent with the increase in laccase activity (Figure 1). Total carbohydrate was depleted after $60 \mathrm{~h}$ of cultivation, while laccase activity was detected from $20 \mathrm{~h}$ of cultivation and maintained high activity until $80 \mathrm{~h}$ of cultivation (Figure 1). The maximum specific growth rate $\left(\mu_{\max }\right)$ of $P$. neostrigosus I9 was determined by batch fermentation.

From the results, the specific growth rate $(\mu)$ could be determined using Equation (1). The dry weight of $P$. neostrigosus 19 in batch fermentation was plotted against cultivation time, and the maximum specific growth rate $\left(\mu_{\max }\right)$ was determined by the slope of the tangent line during a rapid increase in dry weight (Figure 2). At the beginning, the biomass entered a lag phase followed by an exponential growth phase in the growth curve. Biomass concentration and laccase activity increased simultaneously as the fungus entered the exponential phase. Assuming that $x_{\max }=6.70 \mathrm{~g} / \mathrm{L}$, a plot of Equation (1) corresponds to $\mathrm{x}_{0}=0.79 \mathrm{~g} / \mathrm{L}$. The maximum specific growth rate ( $\mu$ max) of P. neostrigosus $\mathrm{I} 9$ was $0.075 \mathrm{~h}^{-1}$, and this value was used to determine the dilution rate (D) in the continuous culture. In this work, the dilution rate of the continuous fermentation was set lower than the maximum specific growth rate to avoid washout. 


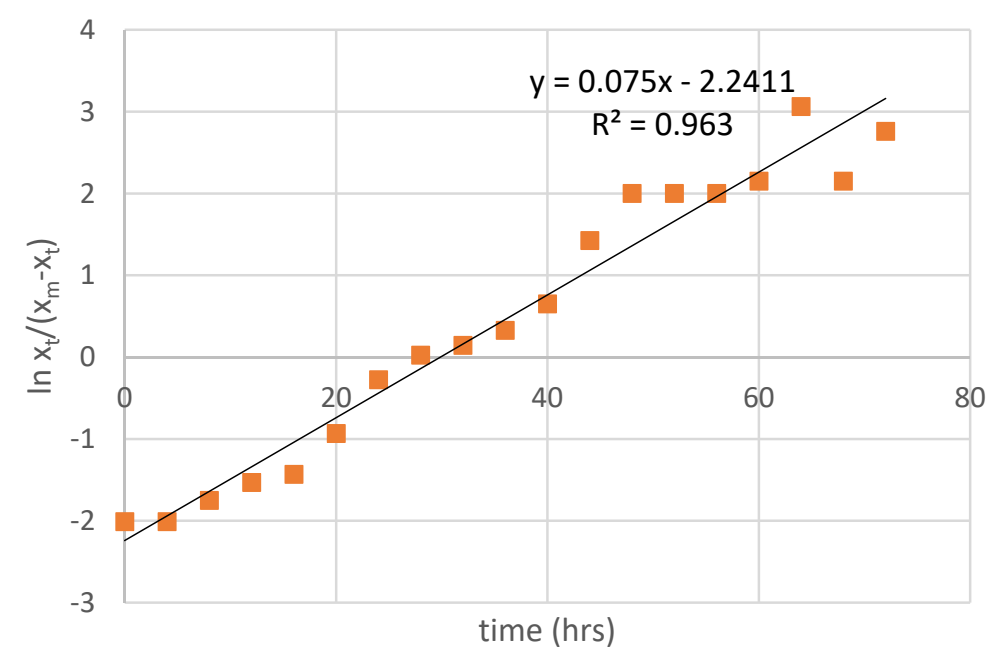

Figure 2. Determination of the maximum specific growth rate $\left(\mu_{\max }\right)$ of $P$. neostrigosus 19 cultured in $1.5 \mathrm{~L}$ tomato juice medium (diluted $1: 3 \mathrm{v} / \mathrm{v}$ ) in batch culture at $28^{\circ} \mathrm{C}$ and $750 \mathrm{rpm}$.

\subsubsection{The Kinetic Model of Laccase Formation}

The basis of the kinetics of product formation is expressed by the Luedeking-Piret equation. $\alpha$ and $\beta$ are constants related to culture conditions. Therefore, from the results in Figure 1 (at 56 to $76 \mathrm{~h}$ of cultivation) (Equation (4)), $\beta=0.497 \mathrm{U} /(\mathrm{g} \mathrm{h})$ was calculated. Finally, a plot of $\mathrm{E}-\beta \mathrm{B}(\mathrm{t})$ against time $\mathrm{A}(\mathrm{t})$ (Figure 3) gives a line with slope $\alpha=16.163 \mathrm{U} / \mathrm{g}$ (Equation (3)).

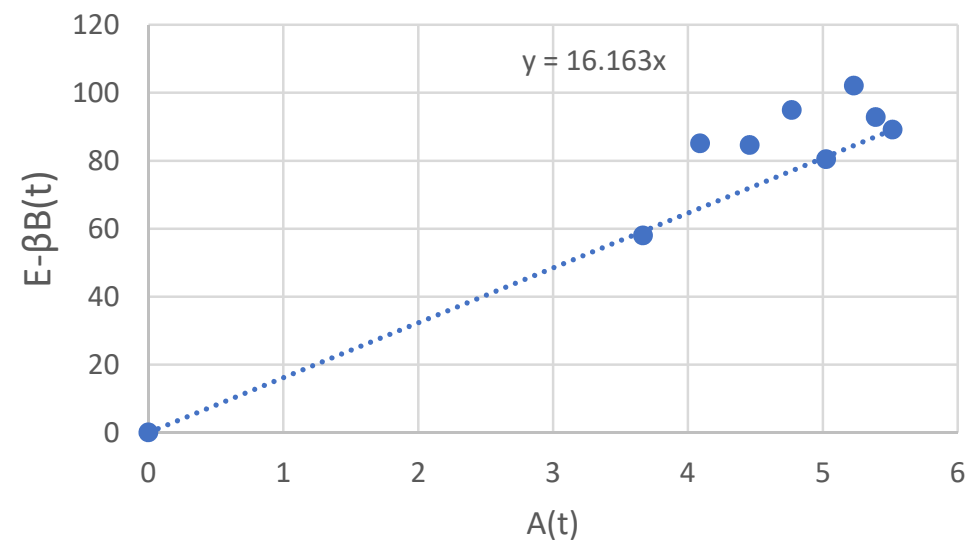

Figure 3. Determination of $\alpha$. The slope of the line was $\alpha(\mathrm{U} / \mathrm{g})$, the growth-associated constant for laccase formation. $\beta$, the biomass-associated constant for laccase formation, was equal to $0.497 \mathrm{U} / \mathrm{g} / \mathrm{d})$.

The results presented in Figure 3 showed that the $\alpha$ value is $16.163 \mathrm{U} / \mathrm{g}$ cell compared to $\beta=0.497 \mathrm{U} /(\mathrm{g} \mathrm{h})$, which means that the laccase production associated with the growth of $P$. neostrigosus I9 and was greater during cell growth in the exponential phase than in the stationary phase. Therefore, if the exponential phase can be prolonged, it is possible that laccase production can also be increased.

\subsection{Cultivation of P. neostrigosus I9 in Continuous Culture for Laccase Production}

By results from batch culture, the maximum dilution rate of continuous culture was $0.075 \mathrm{~h}^{-1}$. Therefore, continuous fermentation of P. neostrigosus I9 was carried out in a 1.5-L fermenter broth using a tomato juice medium (dilution 1:3 $v / v$ ) from batch fermentation. P. neostrigosus $\mathrm{I} 9$ was batch cultured for $24 \mathrm{~h}$ and then switched to continuous cultivation at a dilution rate of $0.05 \mathrm{~h}^{-1}$. The tomato juice medium was fed to the fermenter using a 
peristaltic pump. The retention time (RT) of the cultivation at a dilution rate of $0.05 \mathrm{~h}^{-1}$ was $20 \mathrm{~h}$. Samples were taken every $12 \mathrm{~h}$ until steady state (about $3 \mathrm{RT}$ or $60 \mathrm{~h}$ of cultivation).

To achieve high productivity of laccase enzyme, continuous fermentation was performed. For chemostat culture, the fermenter was operated batchwise until a moderate cell concentration was reached and then operated continuously. Dry weight, laccase activity, and total carbohydrate during fermentation are shown in Figure 4. At a dilution rate of $0.05 \mathrm{~h}^{-1}$, the dry weight at the switchover point $(24 \mathrm{~h})$ of batch fermentation was $6.94 \mathrm{~g} / \mathrm{L}$. The dry weight increased while the total carbohydrate decreased with cultivation time. (Figure 4). The steady state of the culture was reached between 36 and $84 \mathrm{~h}$ after cultivation. At the midpoint of steady state, the concentrations of biomass and residual total carbohydrate were $6.04 \mathrm{~g} / \mathrm{L}$ and $5.38 \mathrm{~g} / \mathrm{L}$, respectively (60 h) (Figure 4). At steady state, stabilization of dry weight was observed from 6.04 to $7.12 \mathrm{~g} / \mathrm{L}$ (Figure 4). However, cell accumulation was observed after $96 \mathrm{~h}$ because $P$. neostrigosus 19 could not be removed from the fermenter due to the low efflux rate. The highest laccase activity of $678.49 \pm 20.39 \mathrm{U} / \mathrm{L}$ was reached after $60 \mathrm{~h}$ and remained constant until $108 \mathrm{~h}$ after cultivation.

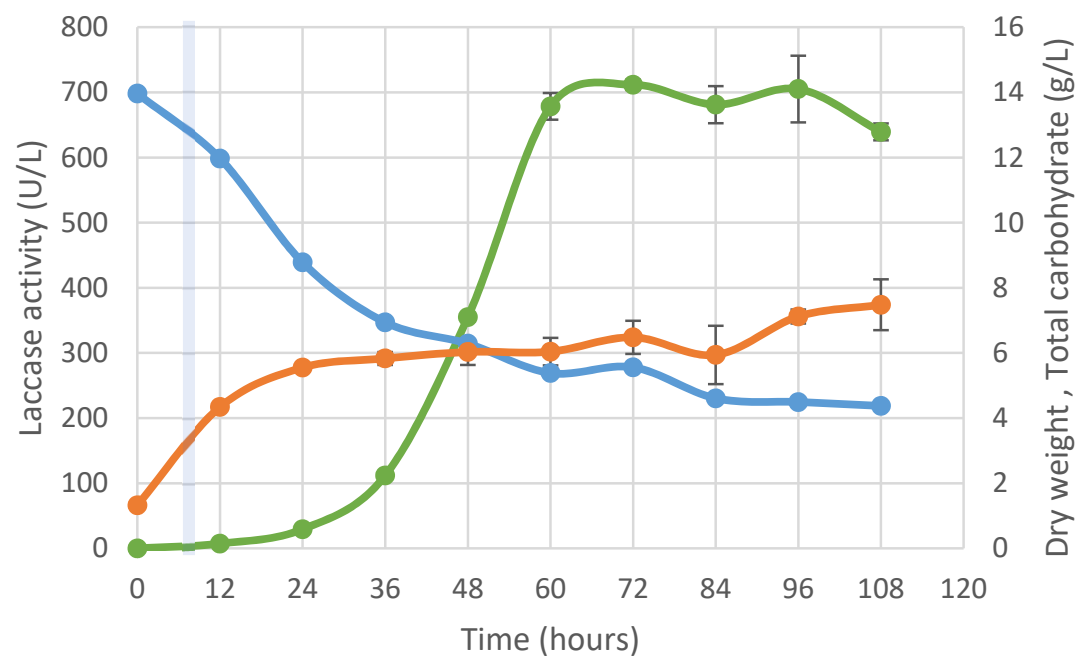

Figure 4. Time course of dry weight (orange), total carbohydrate (blue) and laccase activity (green) during continuous cultivation of $P$. neostrigosus 19 in tomato juice medium at a dilution rate of $0.05 \mathrm{~h}^{-1}$.

\subsection{Effect of Biological Pretreatment Conditions on Delignification}

Rice straw is a lignocellulosic material that could be a promising resource for biorefineries because it is abundant, inexpensive, and not a food. The composition of rice straw was analyzed and shown in Table 2. It can be seen that hemicellulose is the major component $(48.667 \pm 1.790 \%)$ in rice straw, followed by cellulose $(30.671 \pm 1.393 \%)$ and lignin $(15.327 \pm 1.175 \%)$ as minor components. The composition of the raw rice straw indicates a potentially valuable source of fermentable sugar.

Table 2. Biomass composition of rice straw.

\begin{tabular}{cccccccc}
\hline$\%$ & $\begin{array}{c}\text { Acid Soluble } \\
\text { Lignin }\end{array}$ & $\begin{array}{c}\text { Acid Insoluble } \\
\text { Lignin }\end{array}$ & Total Lignin & Cellulose & Hemi-Cellulose & Ash & \%Recovery \\
\hline Rice straw & $4.88 \pm 1.26$ & $10.45 \pm 0.22$ & $15.33 \pm 1.18$ & $30.67 \pm 1.39$ & $48.67 \pm 1.79$ & $2.99 \pm 0.79$ & $97.66 \pm 1.62$ \\
\hline
\end{tabular}

The aim of pretreatment is to remove lignin from the lignocellulosic biomass and to improve the accessibility of cellulose by cellulolytic enzymes. The pretreatment process should be able to increase digestibility to produce reducing sugars by cellulolytic enzymes and limit the formation of fermentation inhibitors. From our previous studies, the optimal conditions for laccase from P. neostrigosus $\mathrm{I} 9$ were $60^{\circ} \mathrm{C}$ and pH 3.0 (Figure S2). However, 
this laccase could not be active for long at a $\mathrm{pH}$ of 3.0 (laccase activity at $60{ }^{\circ} \mathrm{C}$ and a $\mathrm{pH}$ of 3.0 decreased by $50 \%$ within $40 \mathrm{~min}$ ) 0 (Figure S3). Therefore, the $\mathrm{pH}$ kept at $\mathrm{pH} 5.0$, laccase concentration (10-40 U/g substrate), pretreatment time (1-12 h), and temperature $\left(30-60^{\circ} \mathrm{C}\right.$ ) were chosen as experimental design factors to optimize biological pretreatment by ligninolytic enzymes. The effects of the levels of the selected variables for the Box-Behnken design and summaries on the percentage of delignification of pretreated rice straw are shown along with the predicted values in Table 3.

Table 3. Factors of the RSM experimental design. Percentage of delignification as a function of rice straw factors.

\begin{tabular}{|c|c|c|c|c|c|}
\hline \multirow[b]{2}{*}{ Run Order } & \multicolumn{3}{|c|}{ Factors } & \multicolumn{2}{|c|}{$\begin{array}{c}\text { Response Y1 } \\
\text { \%Delignification }\end{array}$} \\
\hline & $\begin{array}{c}\mathrm{A} \\
\left(\mathrm{Temp},{ }^{\circ} \mathrm{C}\right)\end{array}$ & $\begin{array}{c}\text { B } \\
\text { (Time, Hour) }\end{array}$ & $\begin{array}{c}\text { C } \\
\text { (Laccase Conc., } \\
\text { U/g Sub) }\end{array}$ & $\begin{array}{l}\text { Observed } \\
\text { Values }\end{array}$ & $\begin{array}{c}\text { Predicted } \\
\text { Values }\end{array}$ \\
\hline 1 & 30 & 1.00 & 25 & 9.567 & 10.748 \\
\hline 2 & 60 & 1.00 & 25 & 20.278 & 23.978 \\
\hline 3 & 30 & 12.00 & 25 & 40.666 & 40.052 \\
\hline 4 & 60 & 12.00 & 25 & 14.472 & 16.652 \\
\hline 5 & 30 & 6.50 & 10 & 40.801 & 41.315 \\
\hline 6 & 60 & 6.50 & 10 & 16.002 & 16.881 \\
\hline 7 & 30 & 6.50 & 40 & 27.297 & 29.496 \\
\hline 8 & 60 & 6.50 & 40 & 40.902 & 43.761 \\
\hline 9 & 45 & 1.00 & 10 & 35.861 & 36.548 \\
\hline 10 & 45 & 12.00 & 10 & 34.419 & 37.637 \\
\hline 11 & 45 & 1.00 & 40 & 34.406 & 34.178 \\
\hline 12 & 45 & 12.00 & 40 & 52.699 & 55.067 \\
\hline 13 & 45 & 6.50 & 25 & 40.078 & 41.863 \\
\hline 14 & 45 & 6.50 & 25 & 39.923 & 41.863 \\
\hline 15 & 45 & 6.50 & 25 & 40.516 & 41.863 \\
\hline 16 & 45 & 6.50 & 25 & 41.112 & 41.863 \\
\hline 17 & 45 & 6.50 & 25 & 40.111 & 41.863 \\
\hline
\end{tabular}

The adequacy of the model was assessed with ANOVA at a moderate coefficient of determination $\left(\mathrm{R}^{2}=0.9929\right)$, which means that $99 \%$ of the variability of the response could be predicted by the model, only $1.0 \%$ of all variations for the response could not be explained by the model and expresses a good fit. The model F-value of 108.66 and a low probability value $(p<0.0001)$ showed that the model terms were significant. Adequate precision represents the signal-to-noise $(\mathrm{S} / \mathrm{N})$ ratio, and values more than 4.0 indicated that the model precision is adequate. Adequate precision ratio of 37.293 indicated an adequate signal.

The overall effect of the three factors on delignification analyzed by a joint test (Table 4) showed that temperature, incubation time, and laccase concentration had statistically significant effects on delignification ( $p$-values < 0.0001). The interactions between AB, A, C and $\mathrm{BC}$ have significant effects on delignification. The three-dimensional response surfaces showing the relationship between factors on lignin content in rice straw are shown in Figure 5 . 
Table 4. Experimental matrix and results of delignification of rice straw.

\begin{tabular}{|c|c|c|c|c|c|}
\hline Source & $\begin{array}{l}\text { Sum of } \\
\text { Squares }\end{array}$ & df & $\begin{array}{l}\text { Mean } \\
\text { Square }\end{array}$ & F Value & $\begin{array}{l}p \text {-Value } \\
\text { Prob }>\text { F }\end{array}$ \\
\hline Model & 2209.22 & 9 & 245.47 & 108.66 & $<0.0001$ \\
\hline A-Temp & 88.95 & 1 & 88.95 & 39.38 & 0.0004 \\
\hline B-Time & 222.02 & 1 & 222.02 & 98.28 & $<0.0001$ \\
\hline C-laccase conc. & 99.56 & 1 & 99.56 & 44.07 & 0.0003 \\
\hline $\mathrm{AB}$ & 340.49 & 1 & 340.49 & 150.72 & $<0.0001$ \\
\hline$A C$ & 368.72 & 1 & 368.72 & 163.21 & $<0.0001$ \\
\hline $\mathrm{BC}$ & 97.37 & 1 & 97.37 & 43.1 & 0.0003 \\
\hline A2 & 778.69 & 1 & 778.69 & 344.69 & $<0.0001$ \\
\hline B2 & 127.52 & 1 & 127.52 & 56.45 & 0.0001 \\
\hline $\mathrm{C} 2$ & 85.32 & 1 & 85.32 & 37.77 & 0.0005 \\
\hline Residual & 15.81 & 7 & 2.26 & & \\
\hline Lack of Fit & 14.89 & 3 & 4.96 & 21.56 & 0.0062 \\
\hline Pure Error & 0.92 & 4 & 0.23 & & \\
\hline Cor Total & 2225.03 & 16 & & & \\
\hline Std. Dev. & 1.5 & R-Squared & 0.9929 & & \\
\hline Mean & 33.48 & $\begin{array}{l}\text { Adjusted } \\
\text { R-Squared }\end{array}$ & 0.9838 & & \\
\hline C.V \% & 4.49 & $\begin{array}{l}\text { Predicted } \\
\text { R-Squared }\end{array}$ & 0.8923 & & \\
\hline PRESS & 239.72 & $\begin{array}{l}\text { Adequate } \\
\text { Precision }\end{array}$ & 37.293 & & \\
\hline
\end{tabular}

a

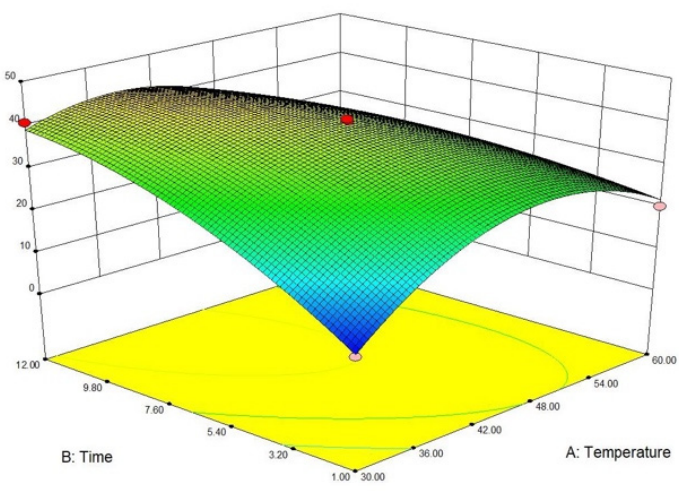

b

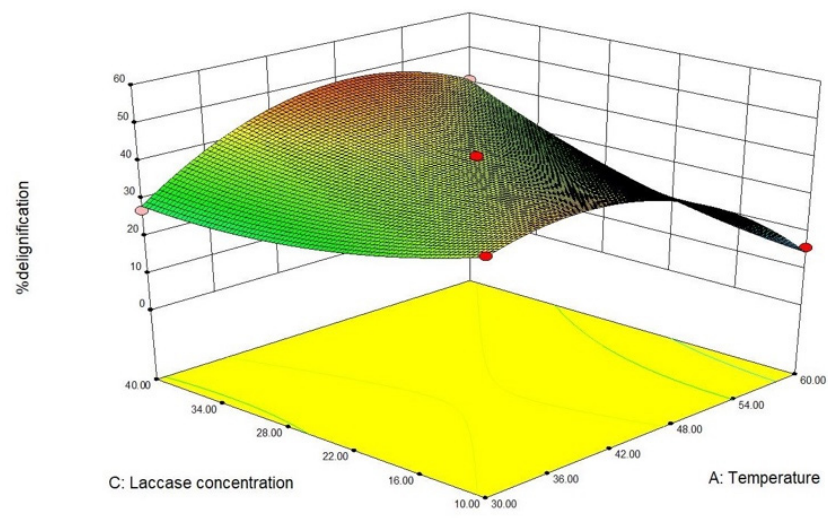

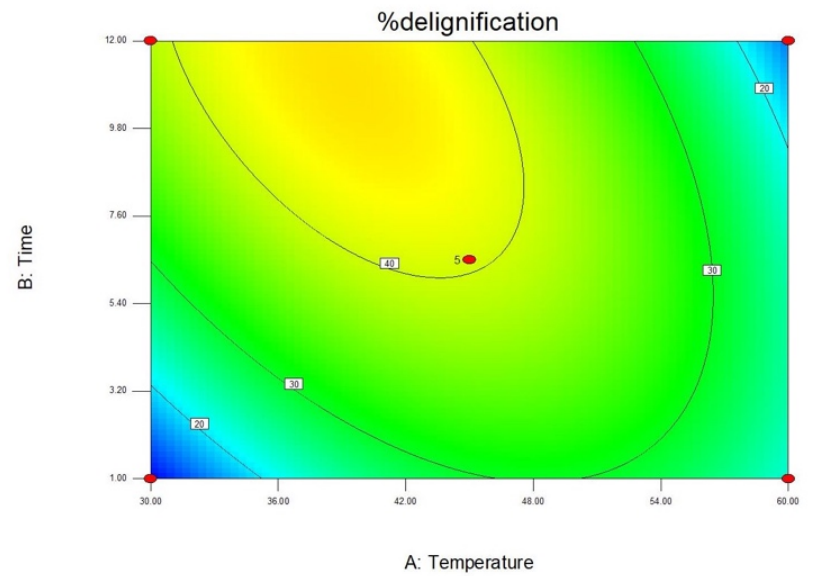

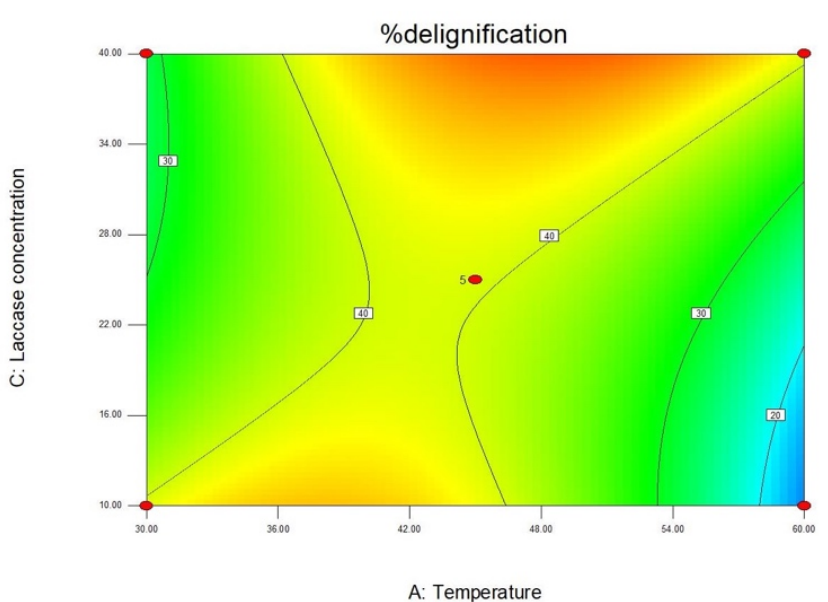

Figure 5. Cont. 

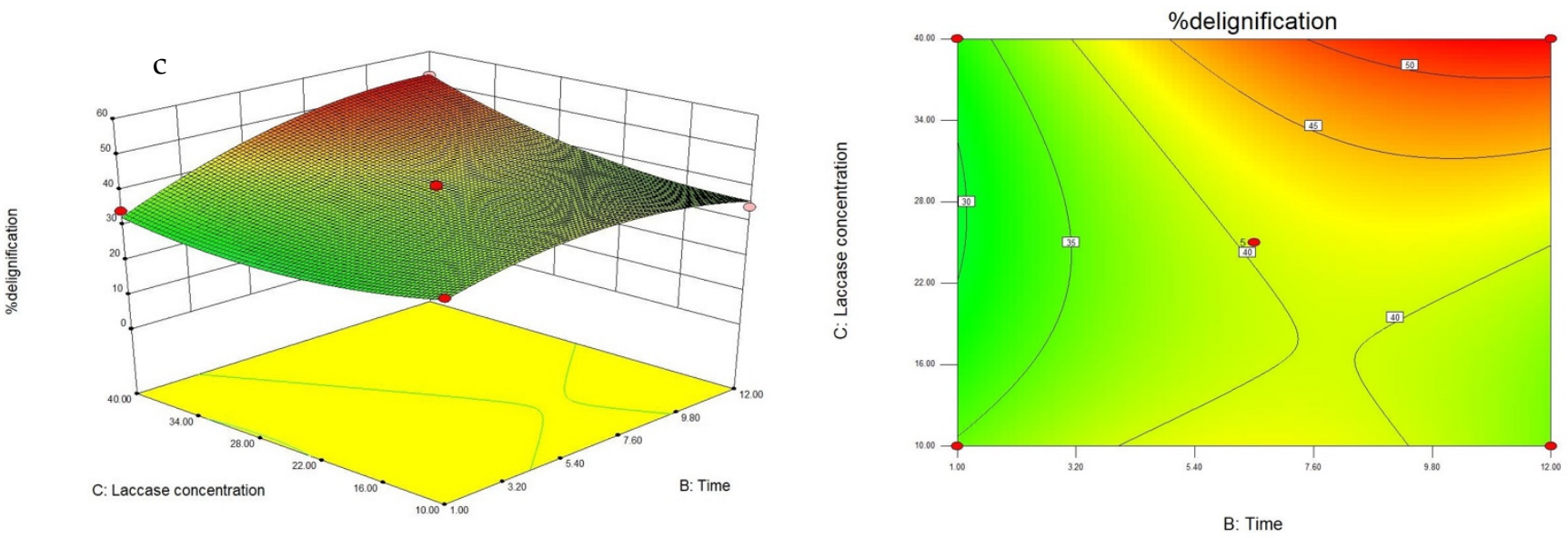

Figure 5. Contour and surface plots of the interaction between time and temperature (a), temperature and laccase concentration (b) and time and laccase concentration (c) on the percentage of delignification.

Figure 5a showed the positive effect of time on percent delignification. The percentage of delignification increased with increasing temperature and time. However, at temperatures higher than $48{ }^{\circ} \mathrm{C}$, delignification decreased with increasing time. Figure $5 \mathrm{~b}$ showed the positive effect of low temperature on percentage of delignification. However, delignification decreased with increasing temperature above $45^{\circ} \mathrm{C}$. Finally, Figure $5 \mathrm{c}$ showed the positive effect of high laccase concentration and long period on percentage of delignification. The percentage of delignification decreased with decreasing laccase concentration under $28 \mathrm{U} / \mathrm{g}$ of rice straw.

The response surface regression procedure in the software Design Expert was used to fit the following second-order polynomial Equation (10). A statistically significant model only with significant terms can be written as follows:

\%delignification $=-54.31+(4.877 \mathrm{~A})+(6.86 \mathrm{~B})-(3.074 \mathrm{C})-(0.111 \mathrm{AB})+(0.043 \mathrm{AC})+(0.06 \mathrm{BC})-\left(0.06 \mathrm{~A}^{2}\right)-$ $\left(0.182 B^{2}\right)+\left(0.02 C^{2}\right)$

According to Equation (10), the factors predicted for optimum delignification (50.28\%) were (temperature) $47^{\circ} \mathrm{C}$, (incubation time) $11.27 \mathrm{~h}$, and (laccase concentration) $38.00 \mathrm{U} / \mathrm{g}$ dry weight. The observed delignification value using the predicted factor was $45.55 \%$, which is close to the predicted value (temperature $45^{\circ} \mathrm{C}$, incubation time $12 \mathrm{~h}$ and laccase concentration $40 \mathrm{U} / \mathrm{g}$ dry weight)

\subsection{Reducing Sugar Production by Using Optimized Biological Pretreatment and Saccharification Processes of Rice Straw}

Reducing sugar concentration and productivity of reducing sugars (yield) from different pretreatment methods are shown in Table 5. Steam explosion pretreatment showed the highest digestibility (reducing sugar $4.75 \pm 0.15 \mathrm{~g} / \mathrm{L}$ within $24 \mathrm{~h}$ ), while enzyme-pretreated rice straw and non-pretreated rice straw gave $3.06 \pm 0.14 \mathrm{~g} / \mathrm{L}$ and $1.57 \pm 0.32 \mathrm{~g} / \mathrm{L}$ within $36 \mathrm{~h}$ and $12 \mathrm{~h}$, respectively. The lowest content of reducing sugars $(0.27 \pm 0.01 \mathrm{~g} / \mathrm{L})$ was recorded when the acid-pretreated rice straw was digested by cellulolytic enzymes. The steam explosion method still gave the highest productivity $(23.74 \%)$ while the biological pretreatment, non-pretreatment, and acid pretreatment gave $15.31 \%, 7.58 \%$, and $1.36 \%$, respectively. Although biological pretreatment was not the best pretreatment method, it can increase digestibility by cellulolytic enzymes. Therefore, biological pretreatment by ligninolytic enzymes is another option for a low-energy, less chemical, and environmentally friendly process to use biomass as feedstock for biofuel production. 
Table 5. Results of steam explosion, acid treatment, and biological treatment.

\begin{tabular}{cccc}
\hline Rice Straw & $\begin{array}{c}\text { Reducing Sugar } \\
(\mathbf{g} / \mathbf{L})\end{array}$ & Time (Hour) & $\begin{array}{c}\text { Yield \%, Reducing } \\
\text { Sugar/g Substrate }\end{array}$ \\
\hline Steam explosion & $4.75 \pm 0.15$ & 24 & $23.74^{\mathrm{a}}$ \\
\hline Laccase pretreatment & $3.06 \pm 0.14$ & 36 & $15.31^{\mathrm{b}}$ \\
\hline Acid treatment & $0.27 \pm 0.01$ & 36 & $1.36^{\mathrm{d}}$ \\
\hline Non-pretreatment & $1.57 \pm 0.32$ & 12 & $7.58^{\mathrm{c}}$ \\
\hline
\end{tabular}

Note: Means of yield (\%, reducing sugar/g substrate) with difference superscript letter indicated significant difference $(p \leq 0.05)$ according to Duncan's multiple range test.

\subsection{Effect of Biological Pretreatment on Rice Straw Morphology}

The morphology of the rice straw in the non-pretreated and the biologically pretreated samples was analyzed using FT-IR spectroscopy (Figure 6). The shape of the $3700-3000 \mathrm{~cm}^{-1}$ caused broad band changes in the pretreated rice straw, indicating a change from intermolecular to intramolecular $\mathrm{OH}$ bonds. In the fingerprint region, FT-IR showed the same pattern in untreated and pretreated rice straw. This means that both still had the same chemical component and the other chemical structure was not changed. The -OH stretching in lignin at $3421 \mathrm{~cm}^{-1}$ was decreased as indicated. The intensity of the lignin bands at 1593, 1504, and $1234 \mathrm{~cm}^{-1}$ decreased slightly, and the intensity of the band at $1647 \mathrm{~cm}^{-1}$, which is conjugated with carbonyl groups and is mainly from lignin, was also lower. Whereas, the peaks at 1428 and $1458 \mathrm{~cm}^{-1}$ indicated increasing deformation of lignin and carbohydrates [36]. The bands at $1369,1158,875$, and $930 \mathrm{~cm}^{-1}$ assigned to the glycosidic linkage of hemicellulose and cellulose were altered. In short, the lignin structure in rice straw was attacked by the enzyme, and the structure of cellulose and hemicellulose in rice straw was also changed by the enzyme during pretreatment.

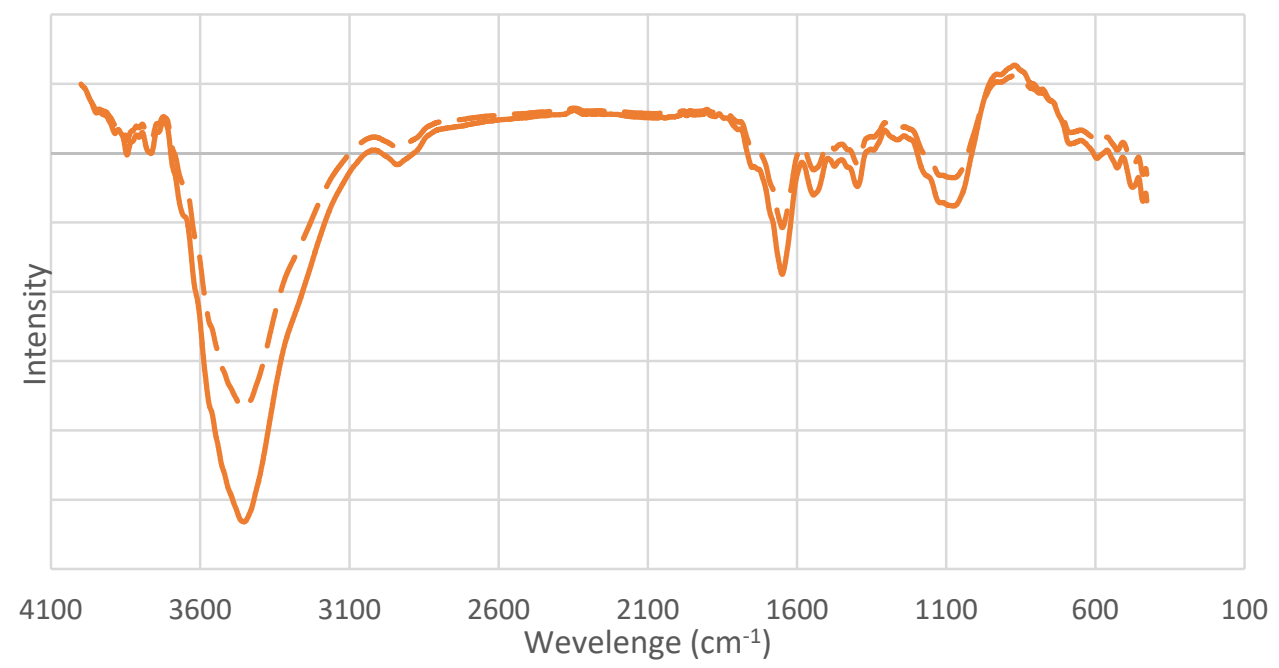

Figure 6. FT-IR spectra of non-pretreated (solid line) and biologically pretreated rice straw (dash line).

\subsection{Reducing Sugar Production from Simultaneous Biological Pretreatment and Saccharification}

The conditions in the reactor for simultaneous pretreatment and saccharification (SPS) were obtained from the results of RSM of pretreatment. The rice straw was pretreated and hydrolyzed simultaneously by laccase and cellulolytic enzymes. The characteristics of the fermenter broth (laccase enzyme production) and hydrolysis reactor broth are shown in Table 6. 
Table 6. Reducing sugar production from non-pretreated and pretreated rice straw.

\begin{tabular}{|c|c|c|c|c|c|c|c|c|c|c|c|c|}
\hline & & \multicolumn{2}{|c|}{$\begin{array}{l}\text { Laccase Activity } \\
\text { (U/L) }\end{array}$} & \multicolumn{2}{|c|}{ Volume (L) } & \multirow{2}{*}{$\begin{array}{l}\text { Rice } \\
\text { Straw } \\
(\mathrm{g} / \mathrm{L})\end{array}$} & \multirow{2}{*}{$\begin{array}{l}\text { Cellulolytic } \\
\text { Enzymes Conc. } \\
\text { (FPU/g) }\end{array}$} & \multicolumn{3}{|c|}{ Reducing Sugar (g/L) } & \multirow{2}{*}{$\begin{array}{c}\begin{array}{c}\text { Theoretical } \\
\text { Sugar }\end{array} \\
\mathrm{g} / \mathrm{L}\end{array}$} & \multirow{2}{*}{$\begin{array}{c}\text { Saccharification } \\
\%\end{array}$} \\
\hline & & Initial & Final & Initial & Final & & & Initial & Final & Production & & \\
\hline \multicolumn{2}{|c|}{ Fermenter broth } & 678.49 & N/A & 1.5 & 1.5 & N/A & N/A & 5.02 & N/A & N/A & N/A & $\mathrm{N} / \mathrm{A}$ \\
\hline \multicolumn{2}{|c|}{ SPS rice straw broth } & 339.24 & 317.18 & 1.5 & 1.5 & 8.72 & 20 & 2.47 & 6.32 & 3.85 & 6.92 & 55.49 \\
\hline \multicolumn{2}{|c|}{ Non-pretreat rice straw } & 0 & 0 & 1.5 & 1.5 & 8.72 & 20 & 0 & 1.13 & 1.13 & 6.92 & 16.30 \\
\hline \multirow{2}{*}{$\begin{array}{l}\text { Crossflow } \\
\text { Concentrator }\end{array}$} & filtrate & 317.18 & 0 & 1.5 & 0.25 & N/A & N/A & 3.84 & 22.27 & N/A & N/A & N/A \\
\hline & Retentate & 317.18 & 283.96 & 1.5 & 1.25 & N/A & N/A & 3.84 & 0.72 & N/A & N/A & N/A \\
\hline
\end{tabular}

The results showed that rice straw was digested as well as the reducing sugar $3.85 \pm 0.15 \mathrm{~g} / \mathrm{L}$ could be detected in the SPS reactor, while non-pretreated rice straw gave only $1.13 \pm 0.10 \mathrm{~g} / \mathrm{L}$ within $12 \mathrm{~h}$ of incubation (Figure 7). This indicated that the enzymatic hydrolysis yield of rice straw was affected by the enzymatic pretreatment process.

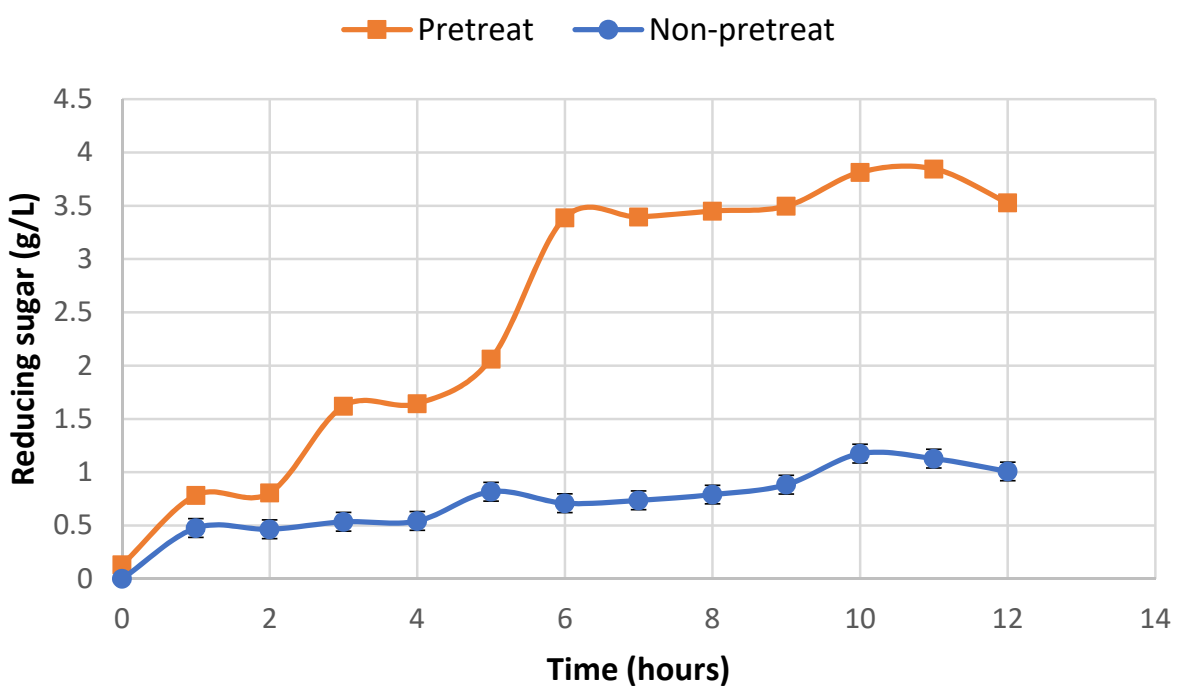

Figure 7. Time course of reducing sugar concentration during hydrolysis with simultaneous biological pretreatment and saccharification of rice straw and untreated rice straw.

The concentrated sugars by tangential crossflow $10 \mathrm{kDA}$ cut-off filtration (Pall corp.) gave a reducing sugar of $22.27 \mathrm{~g} / \mathrm{L}$ and $0.72 \mathrm{~g} / \mathrm{L}$ in the filtrate and the retentate, respectively, which was about six times more concentrated than before. On the other hand, laccase activity of $283.96 \mathrm{U} / \mathrm{L}$ detected in the retentate (Table 6) showed that crossflow filtration can recover about $90 \%$ of the laccase activity. It is possible that the laccase enzyme can be reused for another pretreatment.

\section{Discussion}

\subsection{Cultivation of P. neostrigosus I9 in Continuous Culture for Laccase Production}

In the previous study, tomato juice medium was successfully used for laccase production by P. neostrigosus I9 in shake flasks ( $412.54 \mathrm{U} / \mathrm{L}$ ) [24] (Table 7). Therefore, the tomato juice medium was subsequently tested for laccase production in 2-litre fermenters. It was found that the fungal physiology was strongly influenced by the agitation conditions used, resulting in relatively low laccase production. The laccase activity of $P$. neostriogsus 19 in the shake flask (412.54 U/L) was higher than that in the fermenter tank $(209.96 \pm 0.03 \mathrm{U} / \mathrm{L})$ because mechanical stress in the fermenter tank may affect enzyme production. 
Table 7. The effects of mode of operation on the kinetic characterization of fermentation.

\begin{tabular}{ccccccccccc}
\hline Operation & $\begin{array}{c}\text { Agitation } \\
\text { (rpm) }\end{array}$ & $\begin{array}{c}\text { Time } \\
\text { (Hours) }\end{array}$ & $\begin{array}{c}\text { Dry Weight } \\
(\mathbf{g} / \mathbf{L})\end{array}$ & $\mu_{\max }$ & $\begin{array}{c}\text { Laccase } \\
\text { Activity (U/L) }\end{array}$ & $\begin{array}{c}\text { Laccase } \\
\text { Absolute } \\
\text { Activity (U) }\end{array}$ & $\begin{array}{c}\text { Productivity } \\
\text { U/hr }\end{array}$ & $\mathbf{Y}_{\text {EG }}$ & $\mathbf{Y}_{\text {EX }}$ & Reference \\
\hline $\begin{array}{c}\text { shake } \\
\text { flasks }\end{array}$ & 150 & 144 & $\mathrm{~N} / \mathrm{A}$ & $\mathrm{N} / \mathrm{A}$ & 412.54 & $\mathrm{~N} / \mathrm{A}$ & $\mathrm{N} / \mathrm{A}$ & $\mathrm{N} / \mathrm{A}$ & N/A & {$[24]$} \\
$\begin{array}{c}\text { batch } \\
\text { continuous }\end{array}$ & 750 & 72 & $7.60 \pm 0.11$ & 0.075 & $209.96 \pm 0.03$ & 314.94 & 4.37 & 16.88 & 32.56 & This \\
\hline
\end{tabular}

Note: N/A: not available.

The values of $\alpha$ and $\beta$ depend on the fermentation conditions. The results showed an $\alpha$ - and $\beta$-value of $16.163 \mathrm{U} / \mathrm{g}$ cell and $0.497 \mathrm{U} /(\mathrm{g} h)$, respectively. $\alpha$ is a growth-associated constant $(\mathrm{U} / \mathrm{g})$, which can be considered as the laccase production of the young-age mushrooms, and $\beta$ is a biomass-associated constant $(U /(\mathrm{g} h))$, which means the laccase production coefficient of the older-age mushrooms [28]. This means that the laccase production of $P$. neostrigosus 19 during cell growth was higher in the exponential phase than in the stationary phase.

P. neostrigosus I9 is a fast-growing white rot fungus when cultivated in submerged culture, especially in tomato juice medium. When the agitation rate is above the optimal rate, and fungal growth is inhibited due to insufficient mixing and hydrodynamic shear stress $[37,38]$. Although P. neostrigosus I9 could be tolerated at a high agitation speed when compared to the other white rot fungi (Table 8), the positive correlation turns into a negative one when the rotation rate exceeds $750 \mathrm{rpm}$, indicating that increasing the agitation speed does not promote enzyme formation [26] (Figure S1). This is because fungal morphology in fermenters is also important for energy and oxygen transport [19,39-41]. Furthermore, in this study, laccase activity reached its maximum $(209.96 \pm 0.03 \mathrm{U} / \mathrm{mL})$ at a stirring speed of $750 \mathrm{rpm}$.

Table 8. Maximum laccase activities obtained from different filamentous fungi at bioreactor scale.

\begin{tabular}{|c|c|c|c|c|c|}
\hline Fungus & Type of Reactor & $\begin{array}{c}\text { Type of } \\
\text { Cultivation }\end{array}$ & Inducer & $\begin{array}{l}\text { Max. Laccase } \\
\text { Activity (U/L) }\end{array}$ & Reference \\
\hline $\begin{array}{l}\text { Pycnoporus } \\
\text { cinnabarinus }\end{array}$ & 10-L packed-bed & $\begin{array}{l}\text { SmF, immobilised } \\
\text { on nylon cubes }\end{array}$ & $10 \mathrm{mM}$ VA & 280 & [42] \\
\hline Trametes pubescens & 20-L STR (150 rpm) & SmF, free cells & $2 \mathrm{mM} \mathrm{Cu}^{+2}$ & 61,900 & [43] \\
\hline Neurospora crassa & Capillary membrane & $\begin{array}{l}\text { SmF, immobilised } \\
\text { on membrane } \\
\text { supports }\end{array}$ & $\begin{array}{c}1 \mu \mathrm{M} \\
\text { cycloheximide }\end{array}$ & 10,000 & {$[44]$} \\
\hline $\begin{array}{l}\text { Phanerochaete } \\
\text { flavido-alba }\end{array}$ & $\begin{array}{c}\text { Bioflo III (975 } \mathrm{mL}^{\mathrm{a}} \text {; } \\
70 \mathrm{rpm})\end{array}$ & SmF, free cells & $\begin{array}{c}\text { oil mill } \\
\text { wastewaters }\end{array}$ & 72 & [45] \\
\hline Trametes hirsuta & 1-L fixed-bed & $\begin{array}{l}\text { SmF (immobilised } \\
\text { on stainless steel } \\
\text { sponges) }\end{array}$ & $\mathrm{Cu}^{+2}$ & 2206 & {$[46]$} \\
\hline Trametes versicolor & STR (1 L) & $\mathrm{SmF}$ & $30 \mu \mathrm{M}$ xyldine & 11,403 & [47] \\
\hline T. versicolor & 2-L STR (1.5 L) & SmF free cells & $\mathrm{N} / \mathrm{A}$ & 5.3 & [48] \\
\hline T. versicolor & 5-L STR (1.25 L) & SmF (pellets) & $\mathrm{N} / \mathrm{A}$ & 1385 & [49] \\
\hline Coriolus hirsutus & $\begin{array}{l}\text { 10-L jar fementor } \\
\quad(160 \mathrm{rpm})\end{array}$ & $\begin{array}{l}\text { SmF, free cells, } \\
\text { semi-continuous }\end{array}$ & $0.25 \mathrm{~g} / \mathrm{L} \mathrm{Cu}^{+2}$ & $\begin{array}{c}83,830 \text { (1st } \\
\text { fermentation) } \\
80,730 \text { (2nd } \\
\text { fermentation) }\end{array}$ & [50] \\
\hline Pleurotus ostreatus & $\begin{array}{l}\text { Benchtop fermenter (3 L; } \\
\qquad 200 \mathrm{rpm})\end{array}$ & SmF, free cells & $\begin{array}{c}\text { oil mill } \\
\text { wastewaters }\end{array}$ & 65 & [51] \\
\hline Panus tigrinus & 3-L STR (2 L; 250 rpm) & SmF, free cells & $\begin{array}{l}\text { oil mill } \\
\text { wastewaters }\end{array}$ & 4600 & [52] \\
\hline Panus neostrigosus & 2-L STR (1.5 L; 750 rpm) & \multirow{2}{*}{$\begin{array}{c}\text { SmF (pellets) } \\
\text { Continuous SmF } \\
\text { (pellets) }\end{array}$} & $\mathrm{N} / \mathrm{A}$ & 209.96 & \multirow{2}{*}{ Present study } \\
\hline P. neostrigosus & 2-L STR (1.5 L; 750 rpm) & & $\mathrm{N} / \mathrm{A}$ & 678.49 & \\
\hline
\end{tabular}

Note: N/A: not available; SmF: Submerge fermentation; STR: stirred tank bioreactor. ${ }^{\text {a }}$ The volume in brackets refers to the working volume. 
The laccase activity of $P$. neostrigosus 19 cultured in continuous condition in steady state was $678.49 \pm 20.39 \mathrm{U} / \mathrm{mL}$ and the productivity was $93.82 \mathrm{U} /$ hour. These results were consistent with the predictions of the kinetic model of laccase formation; when the exponential phase was prolonged, laccase production was also increased.

Although the medium flow was continuously fed the reactor, the carbohydrate concentration was not constant because the growth of the fungal walls in the fermenter tank did not come out with the feed out but accumulated in the tank and continued to consume substrate. Numerous mycelial clumps were formed everywhere in the fermenter, such as $\mathrm{pH}$ and DO probes, and the reactor vessel wall. Therefore, the carbohydrate content decreased slightly after the feeding flow. This problem resulted in uncontrollable growth in continuous culture after $84 \mathrm{~h}$ of cultivation. Moreover, this problem should be solved in the future experiments.

The results of optimization could be assessed by means of the kinetic parameters, aside from assessing maximal laccase activity and fermentation duration. These parameters are conducive to a better understanding of the fermentation process and can serve as a reference for enhancement of enzyme production. Therefore, prolonging the exponential phase of P. neostrigosus 19 may increase laccase production. P. neostrigosus 19 gave quite low laccase activity compared to other studies, but white rot fungi could be stimulated to produce laccase by inducers, such as $\mathrm{Cu}^{+2}$ and veratryl alcohol, so this method can increase laccase production by adding it to the fermenter (Table 8).

\subsection{Reducing Sugar Production from Simultaneous Biological Pretreatment and Saccharification}

The overall effect of the three factors on delignification analyzed by a joint test (Table 5) showed that temperature, incubation time, and laccase concentration had statistically significant effects on delignification ( $p$-values < 0.05). The interactions between $A B, A C$, and $\mathrm{BC}$ have significant effects on delignification. The positive effect of low temperature and time gave positive effects on percentage delignification. However, at temperatures above $54{ }^{\circ} \mathrm{C}$, delignification also decreased with increasing time. Zang et al. [53] and Quaratino et al. [54] also reported the maximum laccase activity of Panus rudis at $60{ }^{\circ} \mathrm{C}$ and Panus triginus at $55^{\circ} \mathrm{C}$, respectively. The same results showed that the laccase enzyme of P. neostrigosus $\mathrm{I} 9$ has a higher activity at $60^{\circ} \mathrm{C}$ than at $30^{\circ} \mathrm{C}$, although this high activity can only be maintained for a short period of time. On the other hand, the activity of laccase of $P$. neostrigosus $\mathrm{I} 9$ was better maintained at $30^{\circ} \mathrm{C}$ than at $60^{\circ} \mathrm{C}$ (Figure S3). The percentage of delignification decreased with decreasing laccase concentration under 28 $\mathrm{U} / \mathrm{g}$ of rice straw. This could be due to the fact that laccase enzyme denatured during the pretreatment process. Up to a certain point, the laccase concentration was not sufficient to enter the process, resulting in lower percentage delignification at low laccase concentration. The predicted delignification response was $50.28 \%$, while the observed delignification values using the predicted conditions were $45.55 \%$. The FTIR study showed that the lignin structure, cellulose, and hemicellulose in rice straw changed during pretreatment by the enzyme.

In the hydrolysis phase, the rice straw pretreated with the biological pretreatment method was digested better by cellulolytic enzymes than non-pretreated rice straw. All these results indicated that pretreatment with ligninolytic enzymes is an effective method for pretreating biomass as feedstock for biofuel production, when compared with other pretreatment processes. The lowest content of reducing sugars (less than $0.5 \mathrm{~g} / \mathrm{L}$ ) was found when the rice straw pretreated with acid was digested by cellulolytic enzymes. This could be due to the effect of sulfuric acid which produces inhibitors of cellulolytic enzymes, such as furfural (2-furaldehyde), 5-hydroxymethylfurfural (5-HMF), 4-hydroxybenzaldehyde, and syringaldehyde [55]. Recently, Hu et al. [56] reported that pseudolignin is produced during the repolymerization of lignin because the digestion by acid treatment was incomplete, and this compound can inhibit cellulolytic enzymes. Therefore, these substances must be removed before hydrolysis. 
The reducing sugar yields reported by other researchers during enzymatic hydrolysis of various lignocellulosic biomasses and pretreatment processes are summarized in Table 9. Biological pretreatment yields quite a small reducing sugar compared to the chemical process. However, compared to biological pretreatments and some chemical pretreatments, our techniques achieve quite good results. The yield of reducing sugar depends on the extent of delignification of the lignocellulosic material as the physical protective layer of cellulose is removed, resulting in improved digestibility of cellulose [57,58]. The results showed that rice straw is a potential substrate that yields the highest amount of sugar under optimized conditions.

Table 9. Various studies on reducing sugar production from lignocellulosic biomasses.

\begin{tabular}{|c|c|c|c|c|}
\hline Substrate & Pretreatment & Enzyme Used & $\begin{array}{c}\text { Reducing Sugar Yield } \\
\text { (mg/gdw) }\end{array}$ & Reference \\
\hline Wheat straw / & glycerol & $\begin{array}{c}\text { Penicillium decumbens } \\
\text { JUA10 cellulase and } \\
\beta \text {-glucosidase }\end{array}$ & 900 & [59] \\
\hline Sweet sorghum bagasse/ & $\begin{array}{c}\text { dilute } \mathrm{NaOH}, \\
\text { autoclaving and } \mathrm{H}_{2} \mathrm{O}_{2} \\
\text { alkaline }\end{array}$ & \multirow[t]{2}{*}{ Celluclast $1.5 \mathrm{~L}$} & 909 & [60] \\
\hline Rice husk/ & $\begin{array}{l}\text { peroxide-assisted wet } \\
\text { air oxidation }\end{array}$ & & 210 (Glucose) & {$[61]$} \\
\hline Rice hull & Alkaline peroxide & $\begin{array}{l}\text { Celluclast } 1.5 \mathrm{~L} \text { and } \\
\text { Novozyme } 188\end{array}$ & 154 & {$[30]$} \\
\hline $\begin{array}{l}\text { Corn stover, Miscanthus } \\
\text { and wheat straw }\end{array}$ & Sodium hydroxide & Cellulase Onozuka & $\begin{array}{l}215,258, \text { and } 280 \\
\text { respectively }\end{array}$ & [62] \\
\hline Rice hull & Lime & $\begin{array}{c}\text { Celluclast, Novozyme } 188 \\
\text { and Viscostar }\end{array}$ & 428 & [63] \\
\hline Rice straw & \multirow[t]{2}{*}{ Steam explosion } & $\begin{array}{l}\text { Celluclast } 1.5 \mathrm{~L} \text {, Periconia } \\
\text { sp. bcc } 2871\end{array}$ & 132 & [64] \\
\hline Rice husk/ & & Phanerochete chrysosporium & 447 & [18] \\
\hline Wheat straw / & $\begin{array}{l}\text { Series of white-rot } \\
\text { fungus Euc-1 }\end{array}$ & Onozuka R-10 & 230 & [16] \\
\hline Corn stover/ & $\begin{array}{c}\text { Ceriporiopsis } \\
\text { subvermispora }\end{array}$ & Spezyme CP & 565 (Glucose) & {$[17]$} \\
\hline Rice hull/ & P. ostreatus & Enzyme powder & 398 & {$[65]$} \\
\hline Rice straw & Fungal consortium & Arrowzyme & 492 & [66] \\
\hline \multirow[b]{2}{*}{ Rice straw } & Non-pretreatment & Celluclast 1.5 L & 129 & \multirow[b]{2}{*}{ Present study } \\
\hline & $\begin{array}{l}\text { Ligninolytic enzyme } \\
\text { from } P \text {. neostrigosus I9 }\end{array}$ & Celluclast $1.5 \mathrm{~L}$ & 440 & \\
\hline
\end{tabular}

Compared to other biological pretreatment methods (Table 9), a distinction must be made between pretreatment and saccharification. In other techniques, the fungi are directly inoculated into the lignocellulosic material, which consumes more time, energy, and cost. The techniques of SPS could combine pretreatment and saccharification in a single step by mixing the crude enzyme with commercial cellulase. Therefore, this technique saves time and energy during the process. Moreover, SPS by ligninolytic enzymes is another option for a less chemical and environmentally friendly process to use biomass as feedstock for biofuel production.

\section{Conclusions}

The kinetic model showed that $P$. neostrigosus I9 can produce more laccase in the extensive log phase. Therefore, a continuous process could allow high laccase production. This study highlights the potential use of rice straw, the most abundant agricultural waste, as feedstock for biofuel production. It also confirms the validity of RSM. Pretreatment of rice straw with the ligninolytic enzyme of $P$. neostrigosus 19 under conditions obtained from RSM enhanced a cellulose-rich substrate in an environmentally friendly manner, compared 
to non-pretreatment and other pretreatment methods. An enzyme mixture of laccase and cellulolytic enzymes could produce reducing sugars from rice straw with high digestible solids, low sugar degradation, low toxicity, and low energy consumption in a single step of the simultaneous pretreatment and saccharification process (SPS). High reducing sugar concentration, which was about six times more concentrated, was achieved by tangential crossflow 10 kDA cut-off filtration (Pall Corp.). Besides, crossflow filtration recovered about $90 \%$ of the laccase activity in the retentate indicated that the use of laccase enzyme in another time can be possible. Therefore, SPS by ligninolytic enzymes is another option for a less chemical and environmentally friendly process to use biomass as feedstock for biofuel production.

Supplementary Materials: The following are available online at https:/ / www.mdpi.com/article/10 .3390/jof7100853/s1, Figure S1: Time course of dry weight (A), laccase activity (B), total carbohydrate (C) and $\mathrm{pH}(\mathrm{D})$ and dissolved oxygen (E) during P. neostrigosus I9 cultivation in $2 \mathrm{~L} \mathrm{STR}$ at $28{ }^{\circ} \mathrm{C}$, aeration $1 \mathrm{vvm}$, at various agitation speeds. Values are average of results from triplicate trials; error bars indicate the SD values, Figure S2: Effect of $\mathrm{pH}$ and temperature on laccase activity. Values are average of results from triplicate trials; error bars indicate the SD values (no laccase activity was detected at pH 7.0 and 8.0), Figure S3: Comparison of relative laccase activity as function of $\mathrm{pH}$ at $30{ }^{\circ} \mathrm{C}(\mathrm{A})$ and $60^{\circ} \mathrm{C}(\mathrm{B})$. Values are average of results from triplicate trials; error bars indicate the $\mathrm{SD}$ values.

Author Contributions: Conceptualization, A.T. and S.P.; methodology, A.T.; software, A.T.; validation, A.T. and S.P.; formal analysis, A.T.; investigation, S.P.; resources, A.T. and S.P.; data curation, A.T.; writing—original draft preparation, A.T.; writing—review and editing, S.P.; visualization, A.T.; supervision, S.P.; project administration, S.P.; funding acquisition, S.P. Both authors have read and agreed to the published version of the manuscript.

Funding: This research was financially supported by the National Research Council of Thailand.

Institutional Review Board Statement: Not applicable.

Informed Consent Statement: Not applicable.

Data Availability Statement: The data presented in this study are available on request from the corresponding author. The data are not publicly available due to privacy.

Acknowledgments: The authors are grateful to the National Research Council of Thailand for the financial support and the Department of Microbiology, Faculty of Science, King Mongkut's University of Technology Thonburi, Thailand, for providing the equipment.

Conflicts of Interest: The authors declare no conflict of interest.

\section{References}

1. Phitsuwan, P.; Permsriburasuk, C.; Waeonukul, R.; Pason, P.; Tachaapaikoon, C.; Ratanakhanokchai, K. Evaluation of fuel ethanol production from aqueous ammonia-treated rice straw via simultaneous saccharification and fermentation. Biomass Bioenergy 2016, 93, 150-157. [CrossRef]

2. Kumar, P.; Barrett, D.M.; Delwiche, M.J.; Stroeve, P. Methods for pretreatment of lignocellulosic biomass for efficient hydrolysis and biofuel production. Ind. Eng. Chem. Res. 2009, 48, 3713-3729. [CrossRef]

3. López-Arenas, T.; Rathi, P.; Ramírez-Jiménez, E.; Sales-Cruz, M. Factors affecting the acid pretreatment of lignocellulosic biomass: Batch and continuous process. In Computer Aided Chemical Engineering; Pierucci, S., Ferraris, G.B., Eds.; Elsevier: Amsterdam, The Netherlands, 2010; Volume 28, pp. 979-984.

4. Cardona Alzate, C.A.; Sánchez Toro, O.J. Energy consumption analysis of integrated flowsheets for production of fuel ethanol from lignocellulosic biomass. Energy 2006, 31, 2447-2459. [CrossRef]

5. Mackie, K.L.; Brownell, H.H.; West, K.L.; Saddler, J.N. Effect of sulphur dioxide and sulphuric acid on steam explosion of aspenwood. J. Wood Chem. Technol. 1985, 5, 405-425. [CrossRef]

6. Zhang, X.; Xu, C.; Wang, H. Pretreatment of bamboo residues with Coriolus versicolor for enzymatic hydrolysis. J. Biosci. Bioeng. 2007, 104, 149-151. [CrossRef] [PubMed]

7. Forough, N.; Dzulkefly, A.; Norhafizah, A.; Reza, Z. Evaluation of biological pretreatment of rubberwood with white rot fungi for enzymatic hydrolysis. Materials 2013, 6, 2059-2073.

8. Wong, D.W.S. Structure and action mechanism of ligninolytic enzymes. Appl. Biochem. Biotechnol. 2009, 157, 174-209. [CrossRef] 
9. Eggert, C.; Temp, U.; Eriksson, K.E.L. The ligninolytic system of the white-rot fungus Pycnoporus cinnabarinus: Purification and characterization of the laccase. Appl. Environ. Microbiol. 1996, 62, 1151-1158. [CrossRef]

10. Eriksson, K.L.; Robert, B.; Paul, A. Microbial and Enzymatic Degradation of Wood and Wood Components; Springer: Berlin/Heidelberg, Germany, 1990; Volume 9, p. 407.

11. Hatakka, A. Biodegradation of lignin. Biopolym. Online 2005, 1, 129-179. [CrossRef]

12. Martin, H. Review: Lignin conversion by manganese peroxidase (MnP). Enzym. Microb. Technol. 2002, 30, $454-466$.

13. Thurston, C. The structure and function of fungal laccases. Microbiology 1994, 140, 19-26. [CrossRef]

14. Rodríguez, E.; Pickard, M.A.; Vazquez-Duhalt, R. Industrial dye decolorization by laccases from ligninolytic fungi. Curr. Microbiol. 1999, 38, 27-32. [CrossRef] [PubMed]

15. Mayer, A.M.; Staples, R.C. Laccase: New functions for an old enzyme. Phytochemistry 2002, 60, 551-565. [CrossRef]

16. Dias, A.A.; Freitas, G.S.; Marques, G.S.; Sampaio, A.; Fraga, I.S.; Rodrigues, M.A.; Evtuguin, D.V.; Bezerra, R.M. Enzymatic saccharification of biologically pre-treated wheat straw with white-rot fungi. Bioresour. Technol. 2010, 101, 6045-6050. [CrossRef] [PubMed]

17. Wan, C.; Li, Y. Effectiveness of microbial pretreatment by Ceriporiopsis subvermispora on different biomass feedstocks. Bioresour. Technol. 2011, 102, 7507-7512. [CrossRef] [PubMed]

18. Potumarthi, R.; Baadhe, R.R.; Nayak, P.; Jetty, A. Simultaneous pretreatment and sacchariffication of rice husk by Phanerochete chrysosporium for improved production of reducing sugars. Bioresour. Technol. 2013, 128, 113-117. [CrossRef]

19. Veiter, L.; Rajamanickam, V.; Herwig, C. The filamentous fungal pellet-Relationship between morphology and productivity. Appl. Microbiol. Biotechnol. 2018, 102, 2997-3006. [CrossRef]

20. Olsvik, E.; Kristiansen, B. Rheology of filamentous fermentations. Biotechnol. Adv. 1994, 12, 1-39. [CrossRef]

21. Charles, M. Fermentation scale-up: Problems and possibilities. Trends Biotechnol. 1985, 3, 134-139. [CrossRef]

22. Papagianni, M. Fungal morphology and metabolite production in submerged mycelial processes. Biotechnol. Adv. 2004, 22, 189-259. [CrossRef]

23. Serrano-Carreón, L.; Galindo, E.; Rocha-Valadéz, J.A.; Holguín-Salas, A.; Corkidi, G. Hydrodynamics, fungal physiology, and morphology. Adv. Biochem. Eng. Biotechnol. 2015, 149, 55-90. [CrossRef] [PubMed]

24. Terasawat, A.; Phoolphundh, S. Influence of culture media on growth and laccase production of Panus neostrigosus I9. In Proceedings of the 27th Annual Meeting of the Thai Society for Biotechnology and International Conference Innovative Biotechnolog, Bangkok, Thailand, 17-19 November 2015.

25. Cabaleiro, D.R.; Rodríguez-Couto, S.; Sanromán, A.; Longo, M.a.A. Comparison between the protease production ability of ligninolytic fungi cultivated in solid state media. Process. Biochem. 2002, 37, 1017-1023. [CrossRef]

26. Terasawat, A.; Dandusitapunth, Y.; Phoolpunth, S. Laccase production by Panus neostrigosus I9 through submerged cultivation in various type of bioreactors. In Proceedings of the 7th International Conference on Fermentation Technology for Value Added Agricultural Products (FerVAPP), Khon Kaen, Thailand, 25-28 July 2017.

27. Elibol, M.; Mavituna, F. A kinetic model for actinorhodin production by Streptomyces coelicolor A3(2). Process. Biochem. 1999, 34, 625-631. [CrossRef]

28. Zhao, L.H.; Chen, W.; Wang, L.L.; Sun, H.J.; Zhu, Z. Improvement of laccase production by Pleurotus ostreatus by means of agroindustrial waste and fermentation kinetics. Mycosphere 2017, 1, 147-161. [CrossRef]

29. Chikako, A.; Chizuru, S.; Yoshihiro, U.; Jun, S.; Yoshitoshi, N. Effect of steam explosion pretreatment with ultra-high temperature and pressure on effective utilization of softwood biomass. Biochem. Eng. J. 2012, 60, 25-29. [CrossRef]

30. Saha, B.C.; Iten, L.B.; Cotta, M.A.; Wu, Y.V. Dilute acid pretreatment, enzymatic saccharification and fermentation of wheat straw to ethanol. Process. Biochem. 2005, 40, 3693-3700. [CrossRef]

31. Sluiter, A.; Hames, B.; Ruiz, R.; Scarlata, C.; Sluiter, J.; Templeton, D.; Crocker, D. Determination of Structural Carbohydrates and Lignin in Biomass; Laboratory Analytical Procedure, National Renewable Energy Laboratory (NREL): Denver, Colorado, USA, 2008.

32. Tasman, J.E.; Berzins, V. The permanganate consumption of pulp materials. I. Development of a basic procedure. Tappi 1957, 40, 691-695.

33. Ghose, T.K.; Bisaria, V.S. Measurement of cellulase activities. Pure Appl. Chem. 1987, 59, 257-268. [CrossRef]

34. Nielsen, S.S. Phenol-sulfuric acid method for total carbohydrates. In Food Analysis Laboratory Manual; Food Science Texts Series; Springer: Berlin/Heidelberg, Germany, 2010; pp. 47-53.

35. Miller, G.L. Use of dinitrosalicylic acid reagent for determination of reducing sugar. Anal. Chem. 1959, 31, 426-428. [CrossRef]

36. Genestar, C.; Palou, J. SEM-FTIR spectroscopic evaluation of deterioration in an historic coffered ceiling. Anal. Bioanal. Chem. 2006, 384, 987. [CrossRef]

37. Saat, M.N.; Annuar, M.S.M.; Alias, Z.; Chuan, L.T.; Chisti, Y. Modeling of growth and laccase production by Pycnoporus sanguineus Bioprocess. Biosyst. Eng. 2014, 37, 765-775. [CrossRef]

38. Abd-Aziz, S.; Fernandez, C.C.; Salleh, M.M.; Illias, R.M.; Hassan, M.A. Effect of agitation and aeration rates on chitinase production using Trichoderma virens UKM1 in 2-1 stirred tank reactor. Appl. Biochem. Biotechnol. 2008, 150, 193-204. [CrossRef]

39. Büchs, J. Introduction to advantages and problems of shaken cultures. Biochem. Eng. J. 2001, 7, 91-98. [CrossRef]

40. Tinoco-Valencia, R.; Gómez-Cruz, C.; Galindo, E.; Serrano-Carreón, L. Toward an understanding of the effects of agitation and aeration on growth and laccases production by Pleurotus ostreatus. J. Biotechnol. 2014, 177, 67-73. [CrossRef] 
41. Hess, J.; Leitner, C.; Galhaup, C.; Kulbe, K.D.; Hinterstoisser, B.; Steinwender, M.; Haltrich, D. Enhanced formation of extracellular laccase activity by the white-rot fungus Trametes multicolor. Appl. Biochem. Biotechnol. 2002, 98-100, 229-241. [CrossRef]

42. Schliephake, K.; Mainwaring, D.E.; Lonergan, G.T.; Jones, I.K.; Baker, W.L. Transformation and degradation of the disazo dye Chicago Sky Blue by a purified laccase from Pycnoporus cinnabarinus. Enzym. Microb. Technol. 2000, 27, 100-107. [CrossRef]

43. Galhaup, C.; Haltrich, D. Enhanced formation of laccase activity by the white-rot fungus Trametes pubescens in the presence of copper. Appl. Microbiol. Biotechnol. 2001, 56, 225-232. [CrossRef] [PubMed]

44. Luke, A.K.; Burton, S.G. A novel application for Neurospora crassa: Progress from batch culture to a membrane bioreactor for the bioremediation of phenols. Enzym. Microb. Technol. 2001, 29, 348-356. [CrossRef]

45. Blánquez, P.; Caminal, G.; Sarrà, M.; Vicent, M.T.; Gabarrell, X. Olive oil mill waste waters decoloration and detoxification in a bioreactor by the white rot fungus Phanerochaete flavido-alba. Biotechnol. Prog. 2002, 18, 660-662. [CrossRef]

46. Rodriguez Couto, S.; Sanroman, M.A.; Hofer, D.; Gubitz, G.M. Stainless steel sponge: A novel carrier for the immobilisation of the white-rot fungus Trametes hirsuta for decolourization of textile dyes. Bioresour. Technol. 2004, 95, 67-72. [CrossRef]

47. Tavares, A.P.M.; Coelho, M.A.Z.; Agapito, M.S.M.; Coutinho, J.A.P.; Xavier, A.M.R.B. Optimization and modeling of laccase production by Trametes versicolor in a bioreactor using statistical experimental design. Appl. Biochem. Biotechnol. 2006, 134, 233-248. [CrossRef]

48. Sedarati, M.R.; Keshavarz, T.; Leontievsky, A.A.; Evans, C.S. Transformation of high concentrations of chlorophenols by the white-rot basidiomycete Trametes versicolor immobilized on nylon mesh. Electron. J. Biotechnol. 2003, 6, 104-114.

49. Thiruchelvam, A.T.; Ramsay, J.A. Growth and laccase production kinetics of Trametes versicolor in a stirred tank reactor. Appl. Microbiol. Biotechnol. 2007, 74, 547-554. [CrossRef] [PubMed]

50. Koroleva, O.; Gavrilova, V.; Stepanova, E.; Lebedeva, V.; Sverdlova, N.I.; Landesman, E.; Yavmetdinov, I.S.; Yaropolov, A. Production of lignin modifying enzymes by co-cultivated White-rot fungi Cerrena maxima and Coriolus hirsutus and characterization of laccase from Cerrena maxima. Enzym. Microb. Technol. 2002, 30, 573-580. [CrossRef]

51. Aggelis, G.; Iconomou, D.; Christou, M.; Bokas, D.; Kotzailias, S.; Christou, G.; Tsagou, V.; Papanikolaou, S. Phenolic removal in a model olive oil mill wastewater using Pleurotus ostreatus in bioreactor cultures and biological evaluation of the process. Water Res. 2003, 37, 3897-3904. [CrossRef]

52. Fenice, M.; Giovannozzi Sermanni, G.; Federici, F.; D'Annibale, A. Submerged and solid-state production of laccase and Mn-peroxidase by Panus tigrinus on olive mill wastewater-based media. J. Biotechnol. 2003, 100, 77-85. [CrossRef]

53. Zhang, M.; Wu, F.; Wei, Z.; Xiao, Y.; Gong, W. Characterization and decolorization ability of a laccase from Panus rudis. Enzym. Microb. Technol. 2006, 39, 92-97. [CrossRef]

54. Quaratino, D.; Federici, F.; Petruccioli, M. Production, purification and partial characterisation of a novel laccase from the white-rot fungus Panus tigrinus CBS 577.79. Antonie Van Leeuwenhoek 2007, 91, 57-69. [CrossRef] [PubMed]

55. Zahid, A.; Muhammad, G.; Muhammad, I. Bioethanol productions from rice polish by optimization of dilute acid pretreatment and enzymatic hydrolysis. Afr. J. Biotechnol. 2012, 4, 992-998.

56. Hu, F.; Jung, S.; Ragauskas, A. Impact of pseudolignin versus dilute acid-pretreated lignin on enzymatic hydrolysis of cellulose. ACS Sustain. Chem. Eng. 2013, 1, 62-65. [CrossRef]

57. Karin, Ö.; Renata, B.; Jack, S.; Guido, Z. Effect of hemicellulose and lignin removal on enzymatic hydrolysis of steam pretreated corn stover. Bioresour. Technol. 2007, 98, 2503-2510. [CrossRef]

58. Sannigrahi, P.; Miller, S.J.; Ragauskas, A.J. Effects of organosolv pretreatment and enzymatic hydrolysis on cellulose structure and crystallinity in Loblolly pine. Carbohydr. Res. 2010, 345, 965-970. [CrossRef]

59. Sun, F.; Chen, H. Organosolv pretreatment by crude glycerol from oleochemicals industry for enzymatic hydrolysis of wheat straw. Bioresour. Technol. 2008, 99, 5474-5479. [CrossRef] [PubMed]

60. Cao, W.; Sun, C.; Liu, R.; Yin, R.; Wu, X. Comparison of the effects of five pretreatment methods on enhancing the enzymatic digestibility and ethanol production from sweet sorghum bagasse. Bioresour. Technol. 2012, 111, 215-221. [CrossRef] [PubMed]

61. Banerjee, S.; Sen, R.; Mudliar, S.; Pandey, R.A.; Chakrabarti, T.; Satpute, D. Alkaline peroxide assisted wet air oxidation pretreatment approach to enhance enzymatic convertibility of rice husk. Biotechnol. Prog. 2011, 27, 691-697. [CrossRef] [PubMed]

62. Vintila, T.; Dragomirescu, M.; Croitoriu, V.; Vintila, C.; Bar, H.; Sand, C. Saccharification of lignocellulose-With reference to Miscanthus-Using different cellulases. Rom. Biotechnol. Lett. 2010, 15, 5498-5504.

63. Saha, B.C.; Cotta, M.A. Lime pretreatment, enzymatic saccharification and fermentation of rice hulls to ethanol. Biomass Bioenergy 2008, 32, 971-977. [CrossRef]

64. Harnpicharnchai, P.; Champreda, V.; Sornlake, W.; Eurwilaichitr, L. A thermotolerant beta-glucosidase isolated from an endophytic fungi, Periconia sp., with a possible use for biomass conversion to sugars. Protein Expr. Purif. 2009, 67, 61-69. [CrossRef]

65. Yu, J.; Zhang, J.; He, J.; Liu, Z.; Yu, Z. Combinations of mild physical or chemical pretreatment with biological pretreatment for enzymatic hydrolysis of rice hull. Bioresour. Technol. 2009, 100, 903-908. [CrossRef]

66. Kaur, P.; Kocher, G.; Taggar, M.S. Optimization of saccharification of biological pre-treated rice straw by response surface methodology. Int. J. Curr. Microbiol. Appl. Sci. 2017, 6, 1112-1123. [CrossRef] 